\title{
Adding by Subtracting: How Limited Scope Agreements for Dispute Resolution Representation Can Increase Access to Attorney Services
}

\author{
Kristen M. Blankley*
}

[T] he law has never foreclosed the right of competent, informed citizens to resolve their own disputes in whatever way may suit them. ${ }^{1}$

\section{INTRODUCTION — THE PRoBlem OF THE “At-RISK PARTIES”}

Consider Joan, ${ }^{2}$ a single mother in her mid-thirties with two children under the age of ten at home. Joan lives in a modest three-bedroom bungalow that she and her then-husband bought in 2007, when she was pregnant with her youngest child and still married. She largely relied on her husband to take care of the finances while they were married. Joan's husband left her in mid2009 , and the two of them spent a significant amount of their marital assets on divorce attorneys. Following the divorce, Joan retained the marital home, but she also assumed all of the obligations under the mortgage.

Joan works full time as a hairdresser, and she receives intermittent child support payments from her ex-husband. She lives month-to-month with little savings. Her mortgage payment is her biggest obligation each month, and she is paying down credit card debt and some of her children's medical bills. In 2012, Joan received a terrible surprise in the mail - her mortgage payment increased by more than $\$ 400$ per month. After spending countless hours making phone calls to the bank, she learned that her mortgage was an adjustable-rate mortgage, not the fixed rate mortgage that she had anticipated. The first adjustment came five years after purchasing the house in 2007. Although Joan signed all of the loan paperwork, both at the time of the purchase and when she assumed the mortgage obligation upon her divorce, she was unaware that her mortgage payments could change over

* Thanks to Jean Sternlight, Colleen Medill, Richard Moberly, Andrea Schneider, John Lande, Paul Ladehoff, Richard Reuben, Jen Reynolds, Eric Berger, Alan Frank, John Gradwohl, Chris Fairman, Beth Burkstrand, Victor Quintanilla, Erica Goldberg, Debora Brownyard, Dave Hubbard, and, Jacob Kreutzer for their thoughtful comments while writing and developing this Article. Thank you to Mike Douglass, Jr. for all of his love and support.

${ }^{1}$ Lerner v. Laufer, 819 A.2d 471, 482 (N.J. Super. Ct. App. Div. 2003) (involving the ethical ramifications of a limited scope representation agreement).

2 This account, and the one below, are fictionalized scenarios. 
time. Joan's budget did not take into account this change, and she does not have the money to cover this new mortgage payment. She spent countless more hours on the phone unsuccessfully trying to get a loan modification so that she can make her payments.

Joan, who is now angry, confused, and upset, tried contacting a number of attorneys to see if they could help her modify her mortgage payments so they are more comparable to her old payments. She even went to discuss the issue with one attorney who has a "free consultation." But ultimately, no attorney would agree to take her case against the bank. None of those lawyers told her why they would not represent her, they simply told her that they were too busy and could not take on the representation.

Despite this stated reason, some, perhaps all, of these attorneys turned Joan down because her case is too "small." In the eyes of many attorneys, her case is "small" because the amount of potential return on a contingency fee basis is too low to make the case worthwhile for the attorney, and the amount likely owed on an hourly fee could potentially dwarf any return by Joan. Of course, none of these attorneys asked whether the case is "small" to Joan. In addition, Joan cannot afford to pay a lawyer on an hourly basis to take this case to court and through trial. ${ }^{3}$ Joan is essentially "unrepresentable." Her only realistic options are to bring the case on a pro se basis to request a loan modification or to wait to be sued.

For Joan, court likely is not even her best option. Her true interests are to stay in the family home and continue to pay on her mortgage at a level that is comfortable in her budget. These options, however, could only be achieved in a negotiated settlement (either in unassisted negotiations or in mediation) because courts have little power other than to award monetary damages. ${ }^{4}$ Joan, however, has had a difficult time talking to anyone at the bank, and she does not know what mediation is. In addition, Joan is so angry and upset that she honestly (but perhaps mistakenly) believes that she has a "good case."

Consider Joe, a self-employed plumber who slipped and fell on an unmarked wet floor at a local coffee shop. Joe-who has never carried

${ }^{3}$ In addition, a court may determine that Joan has no cognizable legal claim against her lender.

${ }^{4}$ As a general matter, the courts do not have the authority to modify home loans. Even the bankruptcy courts (which is not something Joan has considered yet) have extraordinarily limited ability to modify home loans. See Diane E. Thompson, Foreclosing Modifications: How Servicer Incentives Discourage Loan Modifications, 86 WASH. L. REV. 755, 832 (2011) ("Outside of [one program], homeowners could access principal reductions through the bankruptcy courts if bankruptcy judges were allowed to modify first lien home loans. Currently, bankruptcy judges may, in at least some circumstances, modify any type of loan except a first lien home loan."). 
medical insurance because he never thought insurance was worth the price he would have to pay on the open market-went to the emergency room following this incident, at the suggestion of the owner of the coffee shop. This visit to the emergency room and follow-up care was significantly more expensive than Joe would have ever imagined. Joe received bills for doctors, hospitals, $x$-rays, and medications, totaling more than $\$ 4,500$. When he asked the shop owner to reimburse him, the owner offered him $\$ 1,250$ if he would sign a letter releasing the store from additional liability. Needless to say, Joe was infuriated. He contacted a number of attorneys in the telephone book, and one or two referred to him by friends, but no one was willing to take his case.

Both Joan and Joe would be significantly better off if they could pay for a few hours of attorney time to help conduct the negotiations, prepare them for mediation, or even attend a mediation with them, than they would be handling the entire litigation pro se. Limited scope attorneys specializing in alternative dispute resolution ("ADR") procedures could help clients like these achieve their goals and resolve their disputes in a timely manner. If more attorneys would consider providing these types of limited services, additional clients (i.e. people considered "nobody's clients" now) could be served in the way that matters most to them.

This Article suggests a new model for attorney representation based on the combined use of limited scope representation ${ }^{5}$ and ADR processes to give otherwise unrepresented parties greater access to justice. ${ }^{6}$ Although none of these three concepts (i.e., access to justice, unbundled services, ${ }^{7}$ and ADR) are new, tying them together in this manner has yet to be considered in the scholarly literature. In addition to providing new resources for clients,

${ }^{5}$ Limited scope representation can be considered a "step in between selfrepresentation and full representation." Russell C. Fagg, New Unbundling Rules in Effect Oct. 1:U.S. Study Says Montana's New Limited-Scope Representation Policy is Gold Standard for the Nation, 36 MONT. LAw. 6, 6 (2011).

${ }^{6}$ This Article focuses on non-prisoner civil cases. Cases involving criminal defendants and incarcerated plaintiffs (such as $\$ 1983$ cases or habeas corpus cases) are outside of the scope of this Article.

${ }^{7}$ Generally speaking, the term "unbundled services" is used interchangeably with "limited scope representation." If we consider "full scope" representation as a "bundle" of legal services, the idea of "unbundling" involves splitting apart the traditional bundle into smaller, discrete tasks. See Forrest S. Mosten, Collaborative Law Practice: An Unbundled Approach to Informed Client Decision Making, 2008 J. DiSP. RESOL. 163, 163 (2008) ("The ability of the attorneys to limit the scope of our services based upon written informed decision making (i.e., consent) of the client is mainstay of both unbundled client coaching of pro se litigants and of Collaborative attomeys."). 
attorneys could expand their practices, gain additional clients, and increase their revenue, all while helping represent the otherwise unrepresentable. As discussed in more detail below, these ideas could also alleviate the court systems as well as provide additional avenues for law schools and legal aid providers to provide services.

Limited scope representation is well within the bounds of the ethical practice of law. The Model Rules of Professional Conduct have long allowed attorneys and clients to limit the scope of the representation. ${ }^{8}$ Model Rule of Professional Conduct 1.2(c) provides: "(c) A lawyer may limit the scope of the representation if the limitation is reasonable under the circumstances and the client gives informed consent." A concise definition of "limited scope representation" is hiring an attorney to perform a "discrete task" and nothing else. ${ }^{10}$ Recently, the ABA endorsed limited-scope representation, or "unbundling," in a Resolution, encouraging more attorneys to engage in this practice. 11 Prior to this Article, most clients, attorneys, and scholars considered those "discrete tasks" to be litigation tasks, such as document drafting and hearing appearances. ${ }^{12}$ This Article shows how that type of thinking is short-sighted (perhaps even misguided) and should be broadened to better serve clients and client interests.

Part II of this Article considers the inefficiencies present in the area of pro se representations, and the benefits of working with counsel, even on a

8 Model Rules of Prof'L CONDUCT R. 1.2(c) (2011). This Rule has been in effect since 2002.

${ }^{9}$ Id.

${ }^{10}$ Kaitlyn Aitken, Unbundled Legal Services: Disclosure is Not the Answer, 25 GEO. J. LEGAL. ETHICS 365, 365 (2012) ("The 'unbundling' of legal services is a practice that consists of attorneys providing pro se litigants with narrow, discrete legal tasks based on what services the litigant needs instead of complete representation."); Michael W. Loudenslager, Giving Up The Ghost: A Proposal For Dealing With Attorney "Ghostwriting" of Pro Se Litigants' Court Documents Through Explicit Rules Requiring Disclosure And Allowing Limited Appearances For Such Attorneys, 92 MARQ. L. REV. 103, 103 (2008). Although Loudenslager defines "limited scope representation" as hiring an attorney to perform a discrete task in litigation, limited scope representation need not be so limited. Limited scope representation could also involve discrete task representation in pre-litigation cases or non-litigation matters.

${ }^{11}$ Resolution, AMERICAN BAR ASSOCIATION STANDING COMMITTEE ON THE DELIVERY OF LEGAL SERVICES (February 2013), www.americanbar.org/content/dam/aba/adminstrative/delivery_legal_services/ls_resoluto in_and_report_108.authcheckdam.pdf. [hereinafter "ABA Resolution"] ("That the American Bar Association encourage practitioners, when appropriate, to consider limiting the scope of their representation as a means of increasing access to legal services.").

12 See infra Part II. 
limited basis. Part III of this Article discusses just how the themes of ADR, limited scope representation, and access to justice can be woven together as a new way to practice law. Part IV presents concrete examples of the types of representation services that could be offered on a limited scope basis. Part V discusses the policy reasons supporting and challenging this proposal in the views of the many different stakeholders at issue, including potential clients, attorneys, courts, and pro bono service providers, including law college clinics. Finally, Part VI concludes by tying together the ideas of limited scope representation, alternative dispute resolution and access to justice. This Article suggests that courts, lawyers, and law schools begin to offer these services more regularly, ultimately creating additional consumer awareness on the part of potential clients. The ultimate goal is to provide more services to those who cannot otherwise afford them, to increase attorney revenue, and to reduce court congestion all at the same time.

\section{ThE "Pro SE Problem"}

In our current legal system, many people who want representation simply do not have access to attorney services. Although criminal defendants have a Sixth Amendment right to counsel, ${ }^{13}$ this right does not apply in civil proceedings. ${ }^{14}$ And yet, these cases are still important to the litigants, especially the ones involving wages, workplace conditions, divorce, child custody, child support, housing (i.e., eviction), bankruptcy, and immigration status. ${ }^{15}$ Judges and attorneys often do not appreciate how "big" these cases

13 Gideon v. Wainright, 372 U.S. 335, 343 (1963). The Sixth Amendment also allows a right to self-representation. See Tiffany Frigenti, Flying Solo Without a License: The Right of Pro Se Defendants to Crash and Burn, 28 TOURO L. REv. 1019, 1025 (2012) (describing the constitutional right to self-representation); Reed Willis, Note, $A$ Fool for a Client: Competency Standards in Pro Se Cases, 2010 BYU L. REV. 321, 321 (2010) ("Further, the Supreme Court found that the rights embodied in the Sixth Amendment imply a right for a criminal defendant to personally 'make his defense,' which includes the right of self-representation") (citation omitted). Because this Article deals with those who would rather proceed with counsel than without, a discussion of the right to selfrepresentation is beyond the scope of this Article.

14 Turner v. Rogers, 131 S. Ct. 2507, 2516 (2011). The Turner case involved a defendant father who was delinquent in his child support payments. Id. at 2509 . The father lost his argument that the state should be required to provide him with assistance of counsel in the case against him for civil contempt of court for not paying ordered child support. Id. at 2520 .

${ }^{15}$ See Benjamin H. Barton \& Stephanos Bibas, Triaging Appointed-Counsel Funding and Pro Se Access to Justice, 160 U. PA. L. REV. 967, 972 (2012) ("There are 
actually are for those involved. In addition, Legal Aid and other non-profit providers of legal services are dramatically underfunded, and clients may not be getting the services they deserve. ${ }^{16}$ Increasing the work load of legal aid providers is a recipe for disaster. ${ }^{17}$

These "at risk" plaintiffs, then, must turn to self-representation in order to vindicate their rights. Unfortunately for them, "at risk" plaintiffs face numerous obstacles during the litigation process due to the litigants' unfamiliarity with the legal landscape. ${ }^{18}$ They are disadvantaged in almost every way. Professor Richard Painter succinctly stated:

In July 2010, the ABA announced a nationwide survey of approximately 1,200 state trial judges on the topic of pro se litigation. The survey showed that an increasing number of litigants are representing themselves in cases involving home foreclosures, domestic relations, housing matters, and consumer issues. The judges also responded that litigants are generally doing a poor job of representing themselves and are burdening the courts. ${ }^{19}$

Given the significant disadvantages, self-represented litigants do not have true access to justice-only the potential for access to justice. Alternative procedures, such as ADR - and a little help from attorneyswould go a long way to solving this problem.

few appointed lawyers even in cases with significant stakes, such as divorce, child custody, child support, housing, and immigration proceedings.").

${ }^{16}$ Id. at $972-77$ (discussing underfunding problems across the country in criminal cases).

${ }^{17}$ BRIAN Z. TAMANAHA, FAILING LAW SCHOOLS 170-71 (2012) (“A recent study by the Legal Services Corporation-a government program to provide legal assistance for low-income people-found that nearly a million cases (one out of every two seeking assistance) were rejected by legal-aid programs owing to insufficient resources.").

18 Benjamin H. Barton, Against Civil Gideon (And For Pro Se Court Reform), 62 FLA. L. REV. 1227, 1228 (2010) ("The current treatment of persons too poor to afford counsel in America's civil courts is an embarrassment and is a serious and growing problem.").

${ }^{19}$ Richard W. Painter, Pro Se Litigation in Time of Financial Hardship - A Legal Crisis and Its Solutions, 45 FAM. L. Q. 45, 45 (2011). See also ABA Resolution, supra note 11, at 2-3 (discussing survey results indicating that low-income and moderateincome families routinely encounter legal problems but do not have the resources to work with an attorney). 


\section{A. Pro Se Litigants Are Unfamiliar With the Law and Procedure}

Undoubtedly, the biggest challenge facing pro se participants is their unfamiliarity with the law and legal procedure. Both of these areas have distinct challenges. Access to the rules of law and legal precedent (discussed below) is a significant problem. ${ }^{20}$ Knowing the law, however, is only a portion of the challenge for anyone who participates in litigation. The other-perhaps larger-challenge lies in understanding the court's procedures and policies, including the rules of procedure, the rules of evidence, and the rules of conduct, among other rules.

Over the last decade-particularly since the Great Recession-the number of self-represented litigants has increased, ${ }^{21}$ leaving more people to

20 The most comprehensive online legal search engines, Westlaw and Lexis, are extraordinarily expensive and some attorneys cannot afford their subscription prices. If attorneys cannot afford these services, the likelihood that an unrepresented person could afford this type of research is next to nil.

${ }^{21}$ See AdMIN. OfFICE of THE U.S. COURTS, Judicial Business of THE UNITED STATES COURTS TBL. S-4 (2004), available at http://www.uscourts.gov/uscourts/Statistics/JudicialBusiness/2004/tables/s4.pdf (citing statistics, including statistics for pro se litigants, for the twelve-month period ending September 30, 2004); see also ADMIN. OFFICE OF THE U.S. COURTS, JUDICIAL FACTS AND FIGURES $\quad$ TBL. $2.4 \quad$ (2006), available at http://www.uscourts.gov/uscourts/Statistics/JudicialFactsAndFigures/2006/Table204.pdf (noting that, in 2004, pro se appellants filed over 25,000 appeals, for $42.7 \%$ of the federal circuit court docket); Jud. Council Cal., STATEWIDE ACTION Plan for Servicing SelfREPRESENTED LITIGANTS 2 (Feb. 2004) (noting that 30\% of civil appeals in California involved at least one pro se participant and the over 4.3 million of all California court users were not represented by counsel); See also Painter, supra note 19, at 46 (reporting that an ABA survey of state trial judges indicated that a "majority $(60 \%)$ of the judges said fewer litigants were being represented by counsel"); Ira P. Robbins, Ghostwriting: Filling in the Gaps of Pro Se Prisoners' Access to the Courts, 23 GeO. J. LeGal ETHICS 271,274 (2010) ("In recent years, the number of pro se litigants has increased dramatically in the United States. Most of these litigants choose to proceed pro se only because they cannot afford full representation."); Stephen Adams, Practical and Ethical Issues When Dealing With a Pro Se Litigant, 54-APR Advocate (Idaho) 24, 24 (2001) (practitioner noting the increase in pro se litigants and anticipating "that economic conditions will cause the number of pro se litigants to increase in the near future"); Stephan Landsman, The Growing Challenge of Pro Se Litigation, 13 LEWIS \& CLARK L. REV. 439, 439 (2009) ("This Article addresses the already substantial and rapidly growing docket of pro se cases in both state and federal courts.").

The ABA also recognized that when "going to state court, most people proceed pro se most of the time." ABA Standing Committee on the Delivery of Legal Services, $A n$ Analysis of Rules That Enable Lawyers to Serve Pro Se Litigants: A White Paper, 45 
navigate the legal labyrinth alone. As one pro se litigant noted "People filing pro se must try to untie the tangled rope of procedure, rules, and precedent on their own. The result is often a morass of indecipherable legal pleadings, forfeiture of basic rights, and clogging of court dockets." 22 Pro se litigants must understand the complex rules of procedure, including complaint drafting, service of process, and motion practice. ${ }^{23}$ In addition, pro se participants may not understand important deadlines (such as the statute of limitations or the deadline for filing a notice of appeal) and may make simple mistakes that would constitute malpractice if an attorney were involved.24 Although the modern era of pro se participation in court proceedings has

FAM. L. Q. 64, 65 (2011) [hereinafter White Paper]; Robert L. Jeffs, The Pro Se Quandry, 23 UTAH B.J. 8, 8 (2010) (noting the increase in pro se litigants in the state of Utah, even during the Great Recession years).

22 Shon R. Hopwood, Slicing Through the Great Legal Gordian Knot: Ways to Assist Pro Se Litigants in their Quest For Justice, 80 ForDHAM L. REV. 1229, 1230-31 (2011) ("Dealing with pro se litigants is not easy . . . I bet avoiding pro se briefs is a common occurrence among clerks in courts across the country."). Mr. Hopwood is a former prison inmate whose essay describes being a pro se litigation participant and helping other prisoners navigate the justice system. A Utah attorney similarly described the complexities of the legal system and the value of legal services: "[T]he judicial system, with its abundant rules and procedures, as well as the mass of laws that govern a particular dispute, makes the services of an attorney exceedingly valuable, if not essential." Jeffs, supra note 21 , at 8.

${ }^{23}$ Recent Supreme Court precedent has arguably added additional burdens to pleading practice. The cases of Bell Atlantic Corp. v. Twombly, 550 U.S. 544 (2008), and Ashcroft v. Iqbal, 556 U.S. 662 (2009), establish that a pleading must demonstrate facial plausibility to withstand a motion to dismiss. See also Adams, supra note 21, at 24 (advising attorneys who receive pro se complaints to determine if they can dismiss them for failure to state a claim and discussing the difficulties pro se parties encounter when trying to issue service of process). Many courts provide special documentation to pro se litigants to help them navigate the legal waters. For example, the District Court of Idaho provides a document to pro se litigants on how to survive a motion for summary judgment. See $i d$. The Bankruptcy Courts of Nebraska provide an informational packet to pro se filers with guidelines for the bankruptcy process, but with a special caution that those filing bankruptcy should have representation. See Filing Without An Attorney, UNITED STATES BANKRUPTCY COURT District OF NEBraska, https://www.neb.uscourts.gov/filing-without-attomey.

${ }^{24}$ See Meehan Rasch, A New Public-Interest Appellate Model: Public Counsel's Court-Based Self-Help Clinic and Pro Bono "Triage" for Indigent Pro Se Civil Litigants on Appeal, 11 J. APP. PRAC. \& PROCESS 461, 462 (2010) ("Improper designation of the record, noncompliance with the rules of court, and a failure to provide coherent briefing of the relevant legal and factual issues on appeal are all issues that often impede lowincome pro se litigants from obtaining equal access to justice in the appellate process."). See also id. at 484 ("Even sophisticated litigants can be baffled by the intricacies of the appellate process."). 
brought about some changes (such as the increased use of forms and provision of legal "information"), ${ }^{25}$ these measures simply do not substitute for an attorney. Without meaningful access to attorneys, self-represented participants do not have true access to justice.

\section{B. Pro Se Litigants Have Fewer Legal Research Resources}

In addition, the pro se participant is unlikely to have significant access to legal references, such as legal precedent, statutes, regulations, and secondary authority. These resources are critical in litigation to show the existence of a cause of action or defense, but they are largely inaccessible to the untrained. The most comprehensive legal information providers (i.e., Westlaw, Lexis Nexis, and Bloomberg) are simply too costly to "one shot" players (and even many attorneys. ${ }^{26}$

Other factors can also impact the research resources of pro se litigants. The homeless only have internet access at public libraries and other public facilities. ${ }^{27}$ Even for those who can access internet resources, those of lower intelligence and the uneducated will have a difficult time understanding legal resources. ${ }^{28}$ Certainly the internet and the explosion of legal "self help" have begun to provided needed resources; ${ }^{29}$ however, today's software and forms

25 See White Paper, supra note 21, at 65 ("Courts in Washington, California, and Florida have established courthouse facilitators who assist with detailed procedural information and form preparation on a one-on-one basis."). For instance, the Washington courts have an excellent description of a courthouse facilitator and the services provided by that person. Courthouse Facilitators, How COURTHOUSE FACILITATORS CAN HELP, http://www.courts.wa.gov/committee/?fa=committee.display\&item_id $=380 \&$ committee_ $\mathrm{id}=108$.

${ }^{26}$ Some of these services are now cost-prohibitive for attorneys, especially those in small firms with limited budgets. If attorneys have a difficult time accessing these online resources, the general public would be significantly more disadvantaged.

${ }^{27}$ Rasch, supra note 24, at 484 ("'O]nline or interactive computer resources are less accessible to low-income and homeless individuals without computers or computer skills.").

${ }^{28}$ Robbins, supra note 21 , at 317 (noting that, at least in the context of prisoner litigation, "many lawyers are unwilling to provide their services pro bono, and most litigants lack the education and resources necessary to succeed pro se"); Kathryn Dahlke, Online Resources Provide Pro Se Guidance and Reveal Pro Bono Opportunities, 38 CoLo. L. 111, 111 (2009) ("Unemployment and homelessness have increased, thus forcing individuals who might normally be able to retain the services of an attorney to represent themselves in legal matters.").

${ }^{29}$ Landsman, supra note 21, at 439 ("Many laypeople believe that with the right guidebook they can master whatever legal challenge they face."). 
simply cannot take the place of lawyers. ${ }^{30}$ Law librarians try to assist patrons in finding legal references, but they do not provide legal advice or otherwise represent clients. Without competent legal representation, the pro se population is seriously disadvantaged in the courts.

\section{Pro Se Litigants Face Biases From Judges And Opposing Counsel}

Although completely unjustified, pro se litigants face huge hurdles from the court system, as well as from opposing counsel. Justice surely is not blind when a pro se litigant submits a poorly written brief, misunderstands orders, misses deadlines, or presents a muddled cross-examination. As a practical matter, people do not like dealing with pro se litigants, because they ask a large number of questions of opposing counsel, the court, and court staff. ${ }^{31}$ Indeed, the learning curve for a new litigant is steep, and few courts, counsel, and staff are interested in spending their time helping someone climb this curve or have the incentive to do so.

Of course, courts must provide a certain amount of leeway for pro se litigants, ${ }^{32}$ especially in interpreting pro se pleadings, ${ }^{33}$ but this may breed resentment, not true assistance. Depending on the type of assistance needed, judges may find themselves outwardly appearing biased in favor of the pro se party, thus compromising their all-important duty of impartiality, while internally dealing with frustration and other hostility toward the pro se party ${ }^{34}$ especially when the parties eat at the court's patience. ${ }^{35}$ Pro se cases

${ }^{30} \mathrm{Id}$. at 456 (describing some legal software available and how they are insufficient to replace the help that an attorney can give).

${ }^{31}$ Hopwood, supra note 22, at 1230. See also Painter, supra note 19 , at 46 (reporting that $71 \%$ of the judges surveyed who responded that the courts are negatively impacted by pro se parties stated that these litigants used "more staff time for assistance"); Barton, supra note 18, at 1230 ("[L]awyers, in comparison to pro se litigants, make every judge's job easier.").

32 Adams, supra note 21, at 24 (discussing leeway given to pro se participants); id. (citing Karim-Paahi v. Los Angeles Police Dep't, 839 F.2d 621, 623 (9th Cir. 1988) (discussing extra protections given to pro se litigants)). See also Painter, supra note 19, at 46 (noting that courts sometimes "compromise [ ] impartiality to avoid injustice to unrepresented parties").

${ }^{33}$ Haines v. Kerner, 404 U.S. 519, 521 (1972) (holding a pro se complaints to "less stringent standards" than those drafted by attorneys). See also Erickson v. Pardus, 551 U.S. 89, 94 (2007) (noting that pro se complaints should be "liberally construed").

${ }^{34}$ Hon. Robert Bacharach, Judicial Advocacy in Pro Se Litigation: A Return to Neutrality, 42 IND. L. REV. 19, 31 (2009) ("Intangibly, judicial benevolence has resulted in a softening of the distinction between advocacy and neutrality."); Landsman, supra note 21 , at 452 ("Judges tend to see the special demands created by pro se litigants as 
simply take longer than cases involving represented parties and courts and opposing counsel may resent the time spent on these cases ${ }^{36}$ putting pro se parties at a disadvantage.

\section{Pro Se Litigants Are Unable to Value Their Own Cases}

One of the many benefits attorneys bring to their clients is their past experience and their ability to judge the value of cases. Often, pro se parties are "one shot" players who have no dealings in the legal system other than their current dispute. Having not seen similar cases in the past, a pro se litigant is likely to have little on which to judge the value of the case. ${ }^{37}$ Even the ABA acknowledged pro se participants' difficulty in case evaluation. These litigants "need assistance with decision making and judgment. They need to know their options, possible outcomes, and the strategies to pursue their objectives." 38

Another reason why pro se litigants are less likely to value their cases appropriately is that they are too close to the conflict. Attorneys, by contrast, are detached from the conflict and able to assess the case from a more neutral

potentially embroiling them in proceedings in ways that suggest partiality."); Rasch, supra note 24, at 463 ("For their part, appellate courts struggle to remain neutral and not give legal advice while providing enough guidance to ensure meaningful access for unrepresented litigants. . . Many pro se litigants require technical assistance at each stage of the appellate process, beyond an initial referral to written directions."). In this situation, the outward appearance of the court will likely not match the internal feelings. While the judges may appear biased in favor of the pro se party, internally, the court may also be harboring resentment and hostility towards that same party for expending valuable court resources unnecessarily.

35 Painter, supra note 19 , at 46 (recounting an instance in which a judge later apologized for delivering a tirade against a pro se litigant during a child custody hearing); Landsman, supra note 21 , at 452 ("[The presence of pro se litigants] can provoke hostility and even biased treatment by court personnel.").

36 Painter, supra note 19 , at 46 ("Ninety percent of those judges who stated courts were negatively impacted said that procedures were slowed.").

${ }^{37}$ ABA Report, supra note 11 , at 5 ("[Unrepresented parties] also need assistance with decision-making and judgment; they need to know their options, possible outcomes and strategies to pursue their objectives."); Adams, supra note 21 , at 25 , cautions attomeys who engage in settlement negotiations with pro se participants. Under Idaho law, an attorney is prohibited from providing the pro se participant with the attorney's opinion of "case value" because that type of communication could result in the inadvertent creation of an attorney-client relationship with the pro se party, thus creating an irreconcilable conflict of interest. See Hopkins v. Troutner, 134 Idaho 445, 447 (Idaho 2000).

38 White Paper, supra note 21, at 66. 
point of view. Although attorneys certainly have biases in favor of their own cases, too, ${ }^{39}$ they can still serve as a "reality check" "to rein in unrealistic expectations" on the part of the pro se participants. ${ }^{40}$ Pro se participants are also unlikely to assess realistically the monetary value (or lack thereof) associated with their own pain and suffering, frustration, anger, time value, and other non-tangibles.

\section{E. Pro Se Litigants Are Less Likely To Understand Alternatives}

Pro se parties, too, are less likely to understand their alternatives to litigation and whether those options would be beneficial in their case. Much to the dismay of the ADR community, terms like "mediation" and "arbitration" are still not household words, and many in the lay community (and sadly, some within the legal community) do not understand the differences in these very different procedures.

If the community at large has only a foggy idea about alternative dispute resolution procedures available, then they will be unlikely to try to employ them on their own. In some cases, individuals are required to mediate or arbitrate, ${ }^{41}$ but without such requirements, pro se parties are unlikely to choose mediation or arbitration on their own. Pro se parties might be better served in ADR procedures because of the benefits of efficiency, flexibility,

${ }^{39}$ Recently, a number of studies have dealt with an attorney's own "optimism bias" (i.e., overestimation of success). See James M. Anderson \& Paul Heaton, How Much Difference Does the Lawyer Make? The Effect of Defense Counsel on Murder Case Outcomes, 122 YALE L.J. 154, 198 n.129 (2012) (noting the overconfidence often exhibited by attorneys); Kyle P. McEntee \& Patrick J. Lynch, A Way Forward: Transparency at American Law Schools, 32 PACE L. REV. 1, 52 (2012) (noting optimism bias in attorneys regarding their own professional careers); Robert J. Condlin, Bargaining Without Law, 56 N.Y. SCH. L. REV. 281, $318 \mathrm{n} .108$ (2012) (stating that the optimism bias on the part of attorneys can cause lawyers to make "inaccurate predictions about litigation outcomes, and this, in turn, can cause them to give unreliable advice to clients about whether to accept a settlement offer or proceed to trial."); Jane GoodmanDelahunty et al., Insighful or Wishful: Lawyers' Ability to Predict Case Outcomes, 16 PSYCHOL. PUB. POL'Y \& L., 133, 141 (2010) (finding lawyers overconfident in their predictions and that the higher level of confidence, the greater the overconfidence proved to be). In some studies, optimism bias tends to increase as the attomey works on the case longer. If that is true, then this proposal for limited-scope representation might give clients more accurate predictions and advice because that aspect of increased confidence over time is eliminated.

40 Landsman, supra note 21 , at 451 .

41 In some employment contracts and consumer contracts, individuals agree, in advance, to certain dispute resolution procedures. Usually, these contracts call for binding arbitration, but some of the contracts require mediation or both procedures in succession. 
informality, autonomy, and remediation. ADR options (especially interestbased options) are often better suited to meet participant's underlying needs - -such as Joan's interest in continued housing, or Joe's interest in medical treatment. Without education as to options, pro se participants will likely end up in court as a default option.

\section{F. Ultimately, Pro Se Litigants Are More Likely To Lose}

Given these uphill challengès, no real surprise exists that pro se litigants often lose in court. Pro se representation has a negative effect on the outcome of a given case. ${ }^{42}$ In one study, pro se litigants only won $3.5 \%$ of their cases ${ }^{43}$ and lost $76.2 \%$ of cases, with the remaining $20.3 \%$ of the cases settling or transferring. ${ }^{44}$ In another study, pro se bankruptcy petitioners were significantly more likely to have their case dismissed without discharge than those debtors represented by counsel. ${ }^{45}$ Even when pro se litigants "win," their only remedy is often money, which may not even be the best remedy to meet the participants' interests.

Many reasons account for these negative outcomes. Some reasons include: "failure to present necessary evidence," "procedural errors," "ineffective witness examination," "failure to properly object to evidence," and "ineffective arguments." 46 These results are unsurprising. As noted above, pro se participants are less likely to understand the law and legal

42 Painter, supra note 19 , at 46 (noting that $62 \%$ of trial judges surveyed indicated that "outcomes were worse for unrepresented parties in litigation").

${ }^{43}$ Certainly, one reason that pro se participants lose so many cases is because they file non-meritorious cases that attorneys would not take. Pro se litigants are not bound by attorney codes of ethics, such as Rule 11 , so cases that attorneys turn down as nonmeritorious may still find their way into the court system.

${ }^{44}$ Landsman, supra note 21, at 442.

45 Raphael I. Pardo, An Empirical Examination of Access to Chapter 7 Relief By Pro Se Debtors, 26 EMORY BANKR. DEV. J. 5, 22 (2009) (showing that bankruptcy courts dismissed $6.4 \%$ of pro se debtor cases, compared to only $0.9 \%$ of cases in which the debtor was represented); see also Victor D. Quintanilla, Beyond Common Sense: A Social Psychology Study of Iqbal's Effect on Claims of Race Discrimination, 17 MICH. J. RACE \& L. 1, 5 (2011) (noting that black pro se participants lost motions to dismiss under Iqbal at the rate of $67.3 \%$ ); Stephen J. Choi et al., The Influence of Arbitrator Backgrounds and Representation on Arbitrator Outcomes, available at $\mathrm{http}$ //papers.ssm.com/sol3/papers.cfm?abstract_id=2109712 (finding that pro se parties in securities arbitrations are less likely to weed out arbitrator bias and thus suffer worse results than those parties represented by counsel).

46 Painter, supra note 19 at 46 (the rate at which judges noticed these types of deficiencies ranged from $94 \%$ to $77 \%$ ). 
procedure, and they are likely to rely on arguments sounding in equity (or perceived equity) rather than on the law. The losing litigants may feel as if they were treated unfairly and have a negative perception of the legal system. ${ }^{47}$ If, instead, attorneys would provide limited scope representation in ADR, they could help pro se parties with the decision that means the most to them-the decision of whether to settle the case and under what circumstances.

\section{ADR AND LIMITED SCOPE REPRESENTATION WORKING TOGETHER}

To date, the primary discussions regarding limited scope representation has revolved around document drafting (i.e., "ghostwriting") 48 and engaging in limited court appearances for otherwise unrepresented parties. ${ }^{49}$ Providing limited assistance in litigation matters, while a worthy goal, is an incomplete goal. Certainly, some legal assistance is better than no legal assistance, but that does not mean that all legal assistance has equal value. It does not. When counsel engages in a limited scope representation to help a client in a small part of the traditional litigation process, that client gains assistance in only the narrowest sense. The attorney has helped the client start (as in complaint drafting) or move along (such as motion practice or limited arguments) in the otherwise long and complicated legal system. In other words, in the current model of litigation assistance of document drafting, discovery work, and

47 Landsman, supra note 21, at 439 ("Pro se cases pose inherent problems: they can cause delays, increase administrative costs, undermine the judges' ability to maintain impartiality and can leave the often unsuccessful litigant feeling as though she has been treated unfairly.").

48 "Ghostwriting" generally refers to "a situation in which a lawyer drafts a pleading or another court document for a client, who then proceeds to file the document pro se." Robbins, supra note 21 , at 276 . Some jurisdictions, such as Nebraska, require that the attorney disclose assistance in the creation of the document, while other states do not. In addition, states have differing arrangements regarding whether the limited act of writing a complaint or other pleading constitutes an "appearance" for which formal withdrawal would be necessary for an attorney to cease providing services. See NEB. RULES. Prof'L CONDUCT R. 3-501.2 (regarding limited scope representation).

${ }^{49}$ Often, the parties are considered "pro se" despite having assistance at some point or another. As one judge noted, the most common examples of limited scope arrangements include "(1) providing legal advice, (2) conducting legal research, (3) gathering facts, (4) conducting discovery, (5) engaging in negotiations, (6) drafting and preparing pleadings, motions, and other court documents, (7) providing limited representation in court, (8) making "referrals to expert witnesses or other counsel," and (9) providing "standby telephone assistance during negotiations or settlement conferences." Hon. Beverly W. Skunals \& Glen H. Sturtevant, Jr., Pro Se Litigation: Best Practices From a Judges ' Perspective, 42 U. RICH. L. REV. 93, 100-01 (2007). 


\section{ADDING BY SUBTRACTING}

court appearances, all the lawyer has done is help the client turn one corner in the large labyrinth of the litigation process. The client is then left to fend for herself through the rest of the labyrinth, encountering all of the difficulties described in the above sections. ${ }^{50}$ As at least one study shows, limited scope representation in the form of complaint drafting does not help plaintiffs achieve substantive relief, even if that type of work might help the unrepresented avoid the pitfalls of default and other technical errors. ${ }^{51}$

The attorneys providing this type of traditional, limited scope representation, then, are short-sighted in considering the ultimate goals and needs of the client. If attorneys were to consider the clients' underlying interests, they would easily discover that clients do not necessarily have an interest in document preparation or representation at hearings per se. The clients more likely have an interest in resolving the underlying problems. Clients have an interest in, for example, retaining the family home, seeing their children following a difficult divorce, paying medical bills, obtaining compensation for time and injury, being heard, hearing an apology, gaining recognition, getting a letter of recommendation, going back to work, obtaining closure, and being treated fairly, to name a few. Lawyers would be serving clients better if they were interviewing and counseling them on their underlying needs, as opposed to considering the services that they could offer in the limited lens of litigation practice. By broadening their consideration of the types of services that lawyers can-and should-provide, attorneys could help clients attain their real goals and interests, and not simply further their way down a path that may not be for them.

Two reasons likely exist for the current state of limited scope representation. First, the lawyers who provide these services often have a "litigation mentality" and are not creative in the area of the delivery of legal services. Second, clients are not demanding settlement services from attorneys, but they are asking for litigation services, instead.

The law and lawyers are always slow in responding to changing circumstances. Lawyers are rarely considered innovators, especially lawyers whose practices involve dispute settling and rights determinations (i.e., litigators). Although the economy has required attorneys to consider new fee arrangements, attorneys have yet to provide radical changes in the services they provide. As discussed below, attorneys must be agents for change and consider how they can best serve the needs of their clients, recognizing the value of settlement procedures to meet client interests.

50 See supra Sections 1 and 2.

51 Jessica K. Steinberg, In Pursuit of Justice? Case Outcomes and the Delivery of Unbundled Legal Services, 18 GeO. J. ON POVERTY L. \& POL'Y 453, 453 (2011). 
Lawyers are certainly not the only ones to blame in this situation. Many clients may simply walk into their offices looking for help on a specific task - such as complaint drafting or representation at a temporary restraining order hearing or at trial to question certain witnesses. When confronted with a specific request, a lawyer may simply consider the request without considering other, perhaps better, options. As noted above, potential clients may be unfamiliar with ADR options and how those options can best meet their needs by satisfying their underlying interests in a more effective manner than traditional litigation. Lawyers, however, should not necessarily succumb to the client's requests for assistance with specific procedures without further discussion. ${ }^{52}$

Attorneys, however, have an ethical responsibility as counselors-even when they are acting in a limited scope capacity. The ethical duties for attorneys acting as counselor include exercising independent judgment, giving candid advice, and considering "moral, economic, social, and political factors" that might be relevant for the client. ${ }^{53}$ In other words, attorneys are not simply agents to do their clients' bidding but are required to exercise professional judgment. In cases involving unsophisticated clients seeking limited technical advice, attorneys may be responsible for advising the client as to the broader questions at issue-and not just the narrow question presented to the attorney. ${ }^{54} \mathrm{~A}$ lawyer's duty may also include advising clients about their alternative dispute resolution options. ${ }^{55}$ In other words, a lawyer's duty may already involve giving clients full and frank advice about their dispute resolution options, including the fact that dispute resolution services might be a better option for limited scope representation.

This Article proposes that limited scope representation be used more often in providing representation in dispute settling procedures and less often in conducting traditional court-required tasks (such as pleading drafting and

52 Note, too, that an attorney's obligation to a client usually involves achieving certain ends, and that the attorney generally has latitude in determining the means to achieve those ends.

53 Model Rules of Prof'L. Conduct R. 2.1 (2011).

54 The comments to the professional rules states:

A client may expressly or impliedly ask the lawyer for purely technical advice.

When such a request is made by a client experienced in legal matters, the lawyer may accept it at face value. When such a request is made by a client inexperienced in legal matters, however, the lawyer's responsibility as advisor may include indicating that more may be involved than strictly legal considerations.

MODEL RULES OF PROF'L CONDUCT R. $2.1 \mathrm{cmt}$. (2011).

55 Id. ("Similarly, when a matter is likely to involve litigation, it may be necessary under Rule 1.4 to inform the client of forms of dispute resolution that might constitute reasonable alternatives to litigation."). 
limited court appearances). By providing clients limited scope representation in dispute resolution services, clients receive the proverbial "biggest bang for their buck." Clients could receive help from attorneys to achieve their underlying interests-resolving the dispute. ${ }^{56}$ As noted above, clients are particularly unlikely to understand the alternative processes available to help resolve their disputes. ${ }^{57}$ Clients also have a difficult time evaluating their own cases because of their closeness to the situation and lack of comparable cases upon which to evaluate the case at hand ${ }^{58}$ Based on all of these factors, attorneys should be counseling their clients that they would be best served to use a limited scope representation for alternative dispute resolution services - if that recommendation makes sense after considering the client's goals and underlying interests..$^{59}$ Making this kind of recommendation falls squarely with an attorney's obligation as counselor and would best serve client interests, if those clients cannot otherwise afford "full service" representation.

\section{TyPeS OF Limited Assistance Within Alternative Dispute RESOLUTION}

This Section considers the types of representation that attorneys could provide within the dispute resolution sphere. Specifically, this Section considers negotiation counseling, negotiation representation, mediation preparation, mediation representation, and arbitration counseling. Each of these types of activities could be undertaken under a limited scope representation agreement, provided that the representation is still reasonable under the circumstances. ${ }^{60}$

\section{A. Negotiation Services or "Settlement Counsel"}

Perhaps one of the most straightforward ways that an attorney could provide a client with services aimed at meeting client interests and resolving

56 For a general discussion on the differences between interests and positions, see Fisher \& URY, GETTING TO YeS: NEgOTIATING AGREEMENT WITHOUT GIVING IN (1981).

57 See supra Sections 1 and 2.

58 See supra Section 3.

59 Of course, not every dispute should be settled, and many clients have an interest in judicial resolution of disputes. Some disputes require the reformation of unconstitutional laws or meeting other interest suitable to judicial involvement. The vast majority of disputes, however, can (and are) resolved by non-judicial means.

60 See Model Rules PROF'L ConduCt R. $1.2 \mathrm{cmt}$. (2011). 
the matter entirely would be to provide the client with negotiation services. The services provided by the attorney could involve negotiation coaching and/or negotiation counsel (i.e., presence at the actual negotiation).

An attorney who acts as settlement counsel could contract with the pro se client that the attorney will provide counsel solely with respect to negotiation services or to act as "settlement counsel" 61 The types of services that could be offered as settlement counsel could include: factual investigation, strategizing, uncovering different settlement options, discussing underlying interests, determining barriers to settlement, other types of counseling, and actual attendance at the negotiation. Note that this list does not include working on discovery issues - the most time-consuming and costly portion of traditional litigation.

As noted above, clients are particularly disadvantaged in bargaining on their own. Pro se parties usually do not have sufficient experience in legal matters or legal resources to determine an approximate case value. In addition, pro se parties are often "too close" to the situation and are, by definition, personally invested in the dispute. Attorneys, particularly settlement counsel, have the ability to give a detached and realistic perspective to the pro se party; they can have a rational discussion with their clients about the expected value of the case and the best strategy to settle at or near that value. Attorneys can also work with clients to consider nonmonetary options and how to incorporate these settlement options as part of an overall negotiation plan.

The decision about whether an attorney should attend the negotiation is a judgment call to be made on a case-by-case basis. Some clients are more comfortable than others in negotiating for themselves. ${ }^{62}$ The pro se party may or may not be sophisticated, educated, or articulate. The other side may or may not be represented by counsel. If the attorney participates, the

61 Having a clear limited scope representation agreement is critical and required by ethical rules. This article does not address the specifics of drafting an agreement for limited scope services. For more assistance on the technical drafting aspects and discussions of the ethical requirements in drafting limited scope agreements, see Stephanie Kimbro, Unbundling Legal Services, 35 FAM. ADVOC. 8 (2012); Kevin M. P. O'Grady, Making the Limited Scope Representation Work, 35 FAM. ADVOCATE 22 (Fall 2012).

62 Some research suggests that women, in particular, are not particularly successful in negotiating for themselves. See generally LINDA BABCOCK, WOMEN DON'T ASK: THE High Cost Of AVoiding Negotiation-AND Positive Strategies for Change (2007). More recent research suggests that women with certain levels of education (such as a law degree) negotiate well on their own, even out-performing men. See Andrea Kupfer Schneider et al., Likeability v. Competence: The Impossible Choice Faced By Female Politicians, Attenuated by Lawyers, 17 DUKE J. GENDER L. \& POL'Y 363, 377 (2010). 


\section{ADDING BY SUBTRACTING}

attorney and client should discuss the extent of the client's involvement (if at all).

In some ways, this type of arrangement for settlement counsel services is similar to the collaborative law arrangement. ${ }^{63}$ In both circumstances, the attorneys and clients agree that they will only be represented for the purposes of settlement and not for the purposes of litigation. ${ }^{64}$ However, acting as settlement counsel is significantly more flexible than the standard process of collaborative lawyering. For instance, unlike collaborative lawyering, both attorneys need not be "settlement counsel." In the collaborative process, both (or all) attorneys must subscribe to the collaborative methods. ${ }^{65}$ In a limited scope representation, the other party may or may not be represented by counsel, and it would make no difference whether an attorney for another party continued on in the case. In addition, a limited scope representation could occur in any area of the law, while the collaborative lawyering model is used primarily, but not exclusively, in the area of family law. 66

The use of settlement counsel would be helpful for otherwise pro se parties in resolving a wide variety of disputes. Pro se parties with disputes in the area of family law, landlord-tenant law, personal injury law, consumer law, and bankruptcy law, to name a few, would benefit from using limited

63 John Lande, Principles for Policymaking About Collaborative Law and Other ADR Processes, 22 OHIO ST. J. ON DISP. RESOL. 619, 625 (2007).

${ }^{64} I d$. According to Lande:

In CL, the lawyers and clients sign a 'participation agreement' committing to the use of an interest-based approach to negotiation from the outset of the case and provide full disclosure of all relevant information. A key element of the participation agreement is the 'disqualification agreement,' which stipulates that both CL lawyers would be disqualified from representing clients if the case is litigated.

${ }^{65}$ Id.; see also Lawrence P. McClellan, Expanding the Use of Collaborative Law: Considerations of its Use in a Legal Aid Program for Resolving Disputes, 2008 J. DisP. RESOL. 465 (2008) (describing the potential for a program of pro bono program involving collaborative law, and posing a suggestion that due to the fact that the model requires two collaborative lawyers, that the program could be limited to cases in which both parties are represented under the program).

66 See, e.g., Deborah Cantrell, The Role of Equipoise in Family Law, 14 J.L. \& FAM. STUD. 63, 71 (2012) ("[C]ollaborative law is now an established way in which a family law matter may be handled."). Collaborative lawyering is certainly expanding into other areas of the law, notably in areas of civil litigation. Based on the author's work in collaborative law groups nationwide, one of the newer footholds for collaborative law is the area of medical malpractice and other types of disputes in the health care industry. Despite the growing numbers in local collaborative bars, still only a small minority of attorneys practice collaborative lawyering. Given the limited number of collaborative lawyers practicing nationwide, using a simpler "settlement counsel" approach would be appropriate in most circumstances. 
scope representation agreements to obtain settlement counsel. Consider the example above involving Joan and her dispute with her mortgage company. Joan may not know her options for reforming or refinancing her current adjustable rate mortgage. Perhaps, if she met with an attorney, that attorney could explore various options with her for resolving her dispute, such as whether she could afford to refinance. Attorneys, especially those who regularly deal in the area of law governing the dispute might be aware of options that the general public may not know. For instance, Joan's attorney could counsel her about making a "cash for keys," offer which would involve the bank giving Joan money to return the property without contest. Banks try to keep these types of settlement arrangements confidential and outside of the knowledge of the general public, but an experienced attorney would be familiar with this type of settlement option. In addition, the attorney could discuss, in a non-threatening way, the realities of her situation and help her determine a strategy in dealing with the bank.

If settlement counsel does not actually participate in the negotiation, settlement counsel could also have an instrumental role in reviewing any negotiated agreements before the pro se client signs them and settles the case. The attorney could review the contract for legality as well as advise whether the settlement comports with the expected value of the case. Many attorneys routinely review post-mediation agreements, ${ }^{67}$ and this type of postnegotiation contract review would be quite a similar process.

Of course, negotiation is a completely voluntary settlement procedure, and both parties have to be amenable to negotiations. Most counsel and most parties are willing to negotiate, or at least willing to consider settlement offers. In the case of a party having settlement counsel, if the attorney discloses the limited relationship with the opposing party, the opposing party might very well be more willing to negotiate with an attorney than with a pro se party. As noted above, ${ }^{68}$ opposing counsel would rather negotiate with another attorney than try to work out a settlement with a pro se party. In situations like these, opposing counsel should welcome the idea of negotiating with an attorney as opposed to continue on the case dealing with a pro se party.

Strategically, it may also be wise to conceal the fact of the limited-scope representation and allow opposing counsel to (incorrectly) assume that the party is represented. If the opposing party or counsel knows that the benefit

${ }^{67}$ See Craig McEwen, Bring in the Lawyers: Challenging the Dominant Approaches to Ensuring Fairness in Divorce Mediation, 79 MNN. L. REV. 1317, 1390 (1995) (arguing that post-mediation review of mediated agreements would be rendered largely unnecessary if more attorneys attended mediations with their clients).

68 See supra Section II. 
of counsel will vanish if the settlement talks break down, the opposing party may have an incentive to not settle and take a chance in court given the fact that most pro se parties lose at trial. This disclosure of the limited scope representation is certainly not required under the ethical rules, and counsel should carefully consider whether the client will be better served by disclosing this fact.

Settlement counsel is also beneficial for the pro se party. In this type of situation, the otherwise pro se party will not expend a large amount of resources for an attorney to conduct discovery and motion practice (which does not directly lead to dispute resolution), but will be putting that money into the area that likely matters most to the party-the resolution of the dispute. By getting expert advice as to negotiation options and strategy, a pro se participant can enter negotiations ready and educated to settle, as well as have someone "in the corner," in the event that questions arise during or after the process.

\section{B. Mediation Services}

In addition to negotiation services, attorneys could also provide limited scope representation as mediation counsel. Mediation counseling activities could include client counseling and interviewing, factual investigation, preparing for mediation, engaging in settlement strategies, attendance at mediation sessions, and post-mediation contract review. As with the idea of settlement counsel, the attorney need not—but certainly could—go to the mediation and provide services during the negotiations themselves. Or, an attorney could simply prepare a client to go to mediation and then work with that client after the mediation in order to review any potential mediated agreements.

All of the same barriers to settlement that exist in negotiation also exist in mediation, including difference in bargaining power, lack of experience, insufficient knowledge of similar cases. Indeed, some scholars argue that imbalances of power are particularly prevalent in mediation. ${ }^{69}$ Having an

${ }^{69}$ Margaret B. Drew, Collaboration and Coercion, 24 HASTINGS WOMEN'S L.J. 79, 91 (2013) ("The enhancement of the imbalance of power to the detriment of the target in mediation and in other settings has been the primary concern of domestic violence lawyers in opposing ADR schemes."); C. Quince Hopkins, Tempering Idealism with Realism: Using Restorative Justice Processes to Promote Acceptance of Responsibility in Cases of Intimate Partner Violence 35 HARV. J.L. \& GENDER 311, 349 n.184 (2012) Hopkins states:

Mediation does not necessarily require or presuppose complete equal bargaining power; most mediators must-as a matter of course-negotiate 
attorney prepare a client for mediation and attend the mediation, particularly an attorney with mediation and settlement experience, would be a valuable use of client resources in considering the entire litigation scheme. Mediation provides a unique opportunity for parties to examine their cases and settlement positions in order to make an informed decision regarding the ultimate resolution of the dispute.

In addition, mediation often provides for the exploration of options, including non-monetary and customized solutions for the parties. Courts, by design, are limited in the types of remedies that can be ordered. For the most part, courts are limited to awarding money damages due all at one time..$^{70}$ Mediators, however, participate in mediation specifically to help parties reach creative solutions. Giving the option of payment over time is a common device that mediators can explore in a frank manner with the parties that courts would have no way of ordering in a judgment. In addition, mediators and attorneys can work with the parties in order to determine where the parties' true interests lie in order to bring about the most desirable outcome for the parties. In Joan's case, mentioned above, a mediator could work with the bank in order to establish any number of viable options that a court simply could not order, such as a refinance of the property, a lower interest rate, or even a "cash for keys" settlement that would pay Joan some amount of money to leave her home and find other, more affordable options.

Unfortunately, the general public is still largely unaware of the mediation opportunities in essentially every dispute. Mediation is still not a common practice within the general community. Although mediation is becoming more commonplace in family law situations, people may not recognize the benefits to mediate other types of disputes. Attorneys, by contrast, should be familiar - or at least more familiar-with the mediation process, and they could propose the idea of mediation to their clients. Clients may not ask for mediation by name, but when attorneys better understand their clients' interest, the attorneys should broach the subject on their own initiative. Attorneys should clearly explain the benefits of mediation and how mediation can be used to resolve their clients' disputes. Then, attorneys

differentials in bargaining power between parties to the mediation. However, it is inappropriate in cases where bargaining power between the parties is grossly unequal. In many, if not all, cases of intimate partner violence, one of the central dynamics of these relationships is the excessive exercise of power and control by the batterer over the victim. These bargaining power inequalities in IPV relationships can lead to unfair settlements, despite the mediator's skill.

${ }^{70}$ Courts also have limited abilities to award, inter alia, injunctive and declaratory relief, but these and other remedies are still quite limited, especially compared to the infinite number of potential solutions that could exist to resolve any given conflict. 


\section{ADDING BY SUBTRACTING}

should defer to their potential clients' wishes as to whether to proceed to mediation..$^{71}$

Mediation is available at virtually every stage of the litigation process. While some points in time may be more optimal than others for conducting a mediation, ${ }^{72}$ mediations are conducted at all points in time during the life of a conflict, including prior to any lawsuit being filed, early in a lawsuit, during discovery, immediately prior to trial, post-judgment, as well as while cases are on appeal. At least one program, the Public Counsel Appellate Law Program in Los Angeles, California, has encouraged lawyers to take on a pro bono representation for the limited purpose of representing a client in appellate mediation. ${ }^{73}$ In other words, no matter what point in time the client seeks legal advice for some type of discrete task, attorneys can recommend mediation to their clients if the process would help the clients meet their underlying objectives.

Mediation, of course, is a voluntary procedure, and both parties must agree to participate. Perhaps an opposing party and counsel would welcome the opportunity to work with opposing counsel in a settlement situation as a chance to have the dispute resolved. Although certainly not an ultimatum, the limited scope attorney should make clear that if the mediation does not occur, then the attorney will not be involved in the case at all, and that the opposing attorney must deal with the client on a pro se basis. For some, simply having the opportunity to work with an attorney might be incentive enough to try the process and mediate the dispute. Given the amount of time and resources pro se parties force on unwilling courts and counsel, ${ }^{74}$ dealing with opposing counsel in a settlement situation may be an attractive option-especially when the opponent client has an interest in fast resolution and efficient procedures.

In other situations, keeping confidential the fact of limited representation might be the best option. On the other hand, the limited-scope attorney may speculate that the opponent would prefer working with an unsophisticated

71 Technically, the decision to mediate may fall within the scope of strategy decisions that a lawyer has sole discretion to determine. MODEL RULES OF PROF'L CONDUCT R. 1.2 (2011). Mediation, however, can be significantly more successful if the client is interested in the process and participates. For these reasons, in a limited scope arrangement, if the client does not want to use an attorney to mediate, mediation might not be the best option in that situation.

72 Research shows that mediation efforts are least likely to be successful at the trial level when motions for summary judgment are fully briefed and awaiting ruling.

73 Rasch, supra note 24 , at 488 (noting that a small handful of cases received pro bono assistance for helping indigent pro se parties with mediation representation).

${ }^{74}$ See supra notes 31 to 36 and accompanying text. 
pro se participant who is likely to lose at trial. If the lawyer fears that the mediation counterpart will simply take advantage of the fact of limited services and deliberately drag out a mediation procedure with no intent of resolution, the attorney can keep the fact of limited representation confidential $^{75}$ and proceed in the mediation with no further discussion of the attorney's role.

In addition, pro se clients might ask the sitting judge to order mediation (or limited-scope counsel could suggest that the pro se clients ask for a mediation order). If the case is ordered to mediation, then the client could have its mediation counsel, ${ }^{76}$ and the other side would be required to participate. The client, then, could proceed to mediation with counsel of choice and participate in this limited manner. A mediator, too, might suggest that a pro se party might receive help from an attorney in order to make certain decisions-such as signing a mediated agreement. Again, to comply with attorney ethics rules, the limited scope attorney should note the limits of the representation (including post-mediation contract review) and that the client will again be pro se if the mediation is ultimately unsuccessful.

\section{Arbitration Services}

Finally, attorneys could provide limited scope arbitration counsel to clients, either in situations involving pre-dispute arbitration agreements or in negotiating and representing clients in post-dispute arbitrations. Because arbitration is intended to be more efficient - in terms of both time and money - than litigation, ${ }^{77}$ pro se clients might be drawn to a procedure such

75 See MODEL Rules Prof'L CONDuCt R. 1.6 (2011) (dealing with client confidences).

${ }^{76}$ In some states, this type of limited scope agreement would not need to be disclosed to the court. For example, in Nebraska, the rules for a limited appearance only apply to limited appearances in court. NEB. RULES. PROF'L CONDUCT \$3-501 .2(d) (2013) ("If, after consultation, the client consents in writing, a lawyer may enter a 'Limited Appearance' on behalf of an otherwise unrepresented party involved in a court proceeding, and such appearance shall clearly define the scope of the lawyer's limited representation.") (emphasis added).

${ }^{77}$ See, e.g., Christine L. Newhall, The AAA's War on Time and Cost, 67 DisP. RESOL. J. 20, 23 (2012) (discussing how arbitrators can take back the reins of the arbitration process to make the procedure more by effectively managing scheduling and pre-hearing practice). Of course, now that arbitration resembles litigation in many respects-including protracted discovery procedures-the traditional efficiencies in arbitration are beginning to be lost. This topic will be addressed infra in the discussion of the importance of contractually limiting the available discovery. 
as arbitration that includes a third-party decision-maker in a trial-like procedure.

Arbitration, like mediation, is a voluntary process, but because a third party makes a largely final and binding decision in the case, parties are oftentimes hesitant to suggest arbitration post-dispute. ${ }^{78}$ Most agreements to arbitrate are made at the beginning of a contractual relationship and prior to any disputes arising. ${ }^{79}$ Arbitration agreements are standard in many consumer contracts, such as contracts for cellular telephones, cable services, and credit cards. ${ }^{80}$ Clients who walk into attorneys' offices may have no choice but to arbitrate their cases if they have already agreed to arbitration in their contracts with their wireless carriers, banks, and employers.

These very clients might be the best types of clients for a limited scope representation when disputes arise. The arbitration process is already intended to be more efficient in terms of cost and time, compared to litigation. If the attorney and the client carefully plan the representation, the services provided by the attorney might be well within the client's budget for dispute-resolution services. Given arbitration's natural efficiencies, creative limited scope counsel could specifically design a streamlined arbitration procedure that makes sense given the circumstances of the individual case. ${ }^{81}$ For example, the parties could, by contract, limit the number of depositions, interrogatories, and other types of discovery. The parties could also limit or

789 U.S.C. $\$ \S 9-10$ (2012) (regarding finality and limited bases of challenging an arbitration award).

${ }^{79}$ Elizabeth Varner, Arbitrating Cultural Property Disputes, 13 CARDOzO J. CONFLICT RESOL. 477, 490-91 (2012) (noting that pre-dispute arbitration agreements are often more economical than those drafted after a dispute arises); Jennifer Schulz, Comment, Arbitrating Arbitrability: How the U.S. Supreme Court Empowered the Arbitrator at the Expense of the Judge and the Average Joe, 44 LOY. L.A. L. REV. 1269, 1269 (2011) ("Over the past twenty years, the use of mandatory pre-dispute arbitration clauses has grown exponentially.").

80 Jodi Wilson, How the Supreme Court Thwarted the Purpose of the Federal Arbitration Act, 63 CASE W. RES. L. REV. 91, 92 (2012) ("Arbitration is omnipresent. If you have a bank account, a credit card, or a cell phone, you have an arbitration agreement."). Note, too, that some major companies, such as Bank of America, are moving away from using arbitration agreements in their consumer contracts. Kathy Chu, Bank of America Ends Arbitration of Credit Card Disputes, USA TODAY, Aug. 13, 2009.

${ }^{81}$ Theodore J. St. Antoine, The Changing Role of Labor Arbitration, 76 IND. L.J. 83, 91-93 (2001) (arguing that arbitration is good for American workers, especially those with relatively low dollar claims because more attorneys will be able to work on these cases as arbitration cases (with its increased efficiencies) even if they could not have taken on the expense of representing these parties in litigation). 
eliminate motion practice. ${ }^{82} \mathrm{With}$ respect to the hearing itself, parties could easily institute time limits, such as a half of a day or a day per side, in order to ensure that costs are reasonable and attorney time is not wasted. Thus, attorneys might be able to serve clients with pre-dispute arbitration agreements by offering this type of unbundled service. Arbitration is always an option, too, for those who would like to utilize the process after the dispute arises, i.e., post-dispute arbitration.

In the last few years, arbitration agreements in the consumer context have become under fire for being "pro business," especially those contracts that limit the consumers' ability to proceed as a class. ${ }^{83}$ The large companies that take advantage of these pro-business individual arbitration requirements could offer to pay for those individuals to be represented by a limited scope representation attorney. Some companies are already offering "bonus" incentives to claimants who receive more at arbitration than they do in settlement offers. ${ }^{84}$ Perhaps this money would be better spent by helping an otherwise pro se participant have representation at the arbitration hearing. 85 Even providing funding for mediation counsel in a multi-step dispute

${ }^{82}$ Motion practice in arbitration is a relatively new phenomenon. As more trial attorneys are arbitrating cases these days, they are incorporating all of the intricacies and procedures of trial into arbitration, including motion practice. Motion practice in arbitration, however, is not a particularly efficient use of time because most arbitrators defer ruling on those preliminary motions until the conclusion of the hearing, thus making them a complete waste of time for the parties. See, e.g., College of Commercial Arbitrators, College of Commercial Arbitrators: Protocols for Expeditious, Cost-Effective Commercial Arbitration, 2011 J. CAN. C. ConsTR. L. 187, 200 (2011) ("Another key source of cost and delay in commercial arbitration is motion practice, as reflected in the poll of National Summit participants.").

83 See AT\&T Mobility LLC v. Concepcion, 131 S. Ct. 1740, 1742 (2001).

${ }^{84} \mathrm{See}$ id. at 1745 (discussing a "premium payment" required by AT\&T if the ultimate resolution of the case in arbitration were less than the mobile company's last settlement offer before the selection of the arbitrator).

85 The Due Process Protocols adopted by the American Bar Association (and others involved in the task force) have been encouraging employers to pay for employee-filed arbitrations since 1995. TASK FORCE ON ALTERNATIVE DISPUTE RESOLUTION IN EMPLOYMENT, Due Process Protocol B(2) (1995), available at www.adr.com. The more recently updated 2010 version contains the same provision. Interestingly, the Consumer Due Process Protocol, also adopted by the American Arbitration Association, does not contain a similar provision regarding the payment of arbitrator fees. National Consumer Disputes Advisory Committee, CONSUMER Due Process Protocol, Principle 9 (2011), available at www.adr.com. 
resolution procedure could help alleviate some of the unconscionability concerns surrounding these contracts. ${ }^{86}$

Summing up, clients are interested in dispute resolution-that is the reason why clients go to attorneys in the beginning. Clients are not interested in a complaint for the sake of having a complaint. They would ultimately like to achieve resolution. Thus, attorneys are currently short-sighted in limiting the types of limited scope services that they offer to mere pleading drafting and motion appearances. These are not the types of activities that achieve resolution. In fact, these are the types of activities that hinder resolution. ${ }^{87}$ Instead, attorneys should engage in a paradigm shift in the way that they are considering offering services-including limited scope representation services. These services should focus on the needs of the clients and resolving their underlying disputes. This section is just the beginning of a conversation on how to achieve those ends.

\section{LIMITED SCOPE REPRESENTATION IN ADR SERVICES MEETS IMPORTANT ACCESS AND FINANCIAL NEEDS FOR ALL PARTICIPANTS}

Using limited scope representation in the manner described above would serve the interests of many different groups, including clients, attorneys, courts, and pro bono service providers. This section considers how limited scope representation in the area of dispute resolution services meets these needs.

${ }^{86}$ Many individual consumers have brought unconscionability challenges to "take it or leave it" arbitration contracts in the financial services and wireless telephone industries. Those consumers have had little success, although the courts do seem concerned about the overall fairness of the contracts. See, e.g., Pendergast v. Sprint Nextel Corp., 691 F.3d 1224, 1234 (11th Cir. 2012) (declining to rule on the unconscionability argument in light of Concepcion); In re Checking Account Overdraft Litigation MDL No. 2036, 485 F. App'x 403, 406 (11th Cir. 2012) (finding a cost-andfee-shifting provision unconscionable in financial services arbitration agreement); Reed v. Florida Metropolitan University, Inc., 681 F.3d 630, 634 (5th Cir. 2012) (not accepting an unconscionability defense in an agreement requiring bilateral arbitration).

${ }^{87} \mathrm{I}$ often tell my students that the worst thing to say in mediation is that you are "going to take this case to court and win!" These types of litigation-based and positional overtures do nothing to advance settlement techniques. In all ADR, other than arbitration, the goal is to convince the other side to settle, not to convince a third-party neutral. 


\section{A. Parties Would Gain Valuable Resources To Settle Cases And Meet Their Interests}

Presumably, the most obvious stakeholders in the discussion of limited scope representation are the parties themselves. Although not every pro se party would like to be represented, many of them would appreciate the help, even on a limited basis. This section considers the many potential advantages of for clients for working in a limited scope representation model focusing on dispute resolution services.

\section{Limited Scope Representation Would Give Increased Access to Attorneys, and Perhaps Increased Access to Justice}

First and foremost, providing limited scope representation for individuals would undoubtedly give access to representation for a larger segment of the population. ${ }^{88}$ No one doubts that financial barriers constitute one of the biggest barriers for the pro se population. ${ }^{89}$ For many, these financial barriers keep the parties from going to court (or taking advantage of other procedures) at all-after all, "avoidance" is probably the most common method of dispute resolution in the entire world. For some, these barriers keep potential plaintiffs from ever seeking to vindicate their rights and resolving their disputes. In other instances, the plaintiffs decide to represent

${ }^{88}$ ABA Resolution, supra note 11 , at 2 ("Lawyers who provide some of their services in a limited scope manner facilitate greater access to competent legal services."); Stephanie L. Kimbro, The Ethics of Unbundling, 33 FAM. ADVOC. 27, 27 (2010) ("Unbundling benefits clients by providing them with what they want: affordable, skilled, and limited legal assistance.").

${ }^{89}$ Landsman, supra note 21, at 441 ("A California court survey in 2005 asked 2414 residents whether 'the cost of hiring an attorney (kept/might keep) you from going to court.' An astounding sixty-nine percent agreed with this proposition.") (citations omitted); id. at 443 ("At the very top of almost every list of the justice-system-based causes is the unavailability of legal services at an affordable price. Virtually every study and report about the pro se issue makes this point."); Heidi Seamon, Unbundling: A Look Over The Basics, 2010 W. VA. LAw. 48, 49 (2010). Seamon states:

Unbundling has the greatest impact on those who cannot afford to hire a lawyer - not only the impoverished, but also the working families who earn just enough to support themselves. ... . [For working families, after] budgeting for expenses such as housing, child-rearing, and transportation, it can seem impossible to gather $\$ 3,000$ to $\$ 5,000$ for a retainer. 
themselves pro se and institute legal action, facing all of the risks above described. ${ }^{90}$

A serious shift in the traditional model of representation strategically disadvantages the individual. More and more, lawyers represent businesses, not individuals. ${ }^{91}$ A number of reasons likely exist for this shift. First, many states adopted versions of "tort reform," which limit the amount of damages available for plaintiffs. For attorneys who work on a contingency-fee basis, traditional tort cases (including medical malpractice) may no longer be profitable. ${ }^{92}$ In addition, the amount of time spent on these cases may not fit within the attorney's portfolio ${ }^{93}$ because the upper limit of available damages, set by statute, do not generate enough income to balance the risks inherent in the contingency-fee contract. In other words, these cases no longer generate sufficient income for attorneys. Second, newer lawyers, specifically, may be financially unable to take cases for individuals on an hourly rate (even in traditional hourly rate types of representation, such as divorce cases) because the amount that these clients can realistically pay does not cover that attorney's overhead, living expenses, and sometimes extraordinary debt load incurred from legal education. ${ }^{94}$ In other words, recent graduates face additional pressure to make money to survive if they are saddled with large debt following law school. This theory, of course, would not apply to lawyers who do not struggle to pay off their student loans or long-time attorneys who no longer have any student loan debt to pay.

Ultimately, the unbundling of legal services and the creation of a limited scope representation arrangement would give otherwise pro se participants increased access to justice. ${ }^{95}$ With as much as eighty percent of the legal

90 Tamanaha, supra note 17, at 171 ("Less than one in five low-income people with legal problems are served by an attorney. These unmet legal needs involve divorces, child custody, eviction from rental property or foreclosure, workplace problems, disputes over insurance claims, and more.").

${ }^{91}$ Landsman, supra note 21 , at 439 ("The legal profession has tilted away from representing individuals and toward representing businesses.").

$92 \mathrm{Id}$. ("Tort reform has set caps on damages awards thereby reducing available contingent fees ....").

93 "Portfolio" in this instance refers to the open cases handled by an attorney or firm. Given that the cases have differing probability of success and differing monetary outcomes, considered together, the outstanding caseload is considered a "portfolio".

94 See Tamanaha, supra note 17, at 170-71.

95 See Amber Hollister, Limiting the Scope of Representation, 71 OR. ST. B. BULL. 9, 9 (2011) ("Legal Aid Services of Oregon still meets less than 20 percent of the legitimate legal needs of Oregon's poor. Because unbundled legal services are often more 
needs of America's poor going unmet, ${ }^{96}$ offering additional limited scope representation should only begin to help meet the legal needs of these "atrisk" litigation participants. The rules of ethics clearly allow for this type of representation, and give "an additional tool available for attorneys to use to provide legal services to a broader range of clients who may not be able to afford comprehensive representation."97 As discussed below, the contractual arrangements between the attorney and client can vary widely depending on the situation, but realistic options might exist to give the otherwise unrepresented increased access to attorneys to help the clients in the situations that matter most, i.e., setting cases and satisfying client interests.

\section{Given the Flexibility of Limited Scope Representation, Parties Have Greater Access to "Voice" in Dispute Resolution}

Using limited scope representation for dispute resolution services gives participants a unique opportunity to express voice in the resolution of their disputes. Unlike traditional limited scope representation services in the area of document drafting and appearance making, limited scope representation services in the area of dispute settling can involve significant and meaningful client involvement-especially when the clients are involved in settlement procedures, such as negotiation and mediation.

Empirical research to date clearly shows that when parties have increased participation and voice, they have increased satisfaction in the process. ${ }^{98} \mathrm{In}$

affordable, unbundling may also increase access to justice for individuals who need legal advice, but are priced out of the traditional legal market.").

96 Steinberg, supra note 51 , at 453.

97 Jeffs, supra note 21, at 9. See also Robbins, supra note 21, at 294 ("Nondisclosure is necessary to protect these lawyers from the burdens of becoming attorneys of record in protracted litigation, and to encourage them to provide the muchneeded service of ghostwriting for disadvantaged prisoner litigants who have no alternative but to proceed pro se.").

98 See Roselle Wissler, Party Participation and Voice in Mediation, 18 DISP. RESOL. MAG. 20, 20 (2011) (discussing the differences between party participation and "voice" in mediation); Landsman, supra note 19, at 457-58 ("This proposition has been confirmed in a number of contexts from tort claims to felony criminal trials in which substantial prison sentences are fixed."). See also Roselle L. Wissler, Representation in Mediation: What We Know From Empirical Research, 37 FORDHAM URB. L.J. 419, 447 (2010). Wisler states:

How well parties believe their representative understands their interests and objectives, and how accurately their representative communicates their views and concerns when speaking for them, may play a large role in parties' sense of voice 
considering the element of "voice," recent research indicates that parties have "voice" in dispute resolution both when they directly participate in the dispute resolution procedure by talking themselves and when their views are adequately explained by counsel. ${ }^{99}$ Attorneys who have had effective client counseling sessions can plan how to present a client's views in an alternative dispute resolution forum in order to best give the client "voice." This "voice" can be achieved either by the client's active participation or by the attorney's presentation of the client's interest and story. Some clients are interested in voicing their story on their own. Others seek an advocate to help communicate the clients' messages in the most advantageous way possible. ${ }^{100}$ Voice can also be achieved by a combination of the attorney's and the client's participation. No matter how the client's "voice" comes through, the client should have increased satisfaction in the process by virtue of the participation. Using limited scope representation services in a meaningful way, such as this, the client's voice is heard loud and clear, thus giving increased satisfaction to the disputant.

\section{Deal with Imbalances in Bargaining Power}

As noted above, one of the serious disadvantages that many (but certainly not all) pro se litigants encounter in the legal system is a lack of bargaining power in the litigation process, especially when dealing with a represented party. ${ }^{101}$ Any number of factors could contribute to the lack of bargaining power, including intelligence, training, access to resources, literacy, communication skills, and education. As with any issue of power, however, the power dynamic can change, depending on the circumstances. Although not all pro se litigants are at a power disadvantage, the potential for power imbalance is a serious concern and one that pro se litigants should be concerned about.

Attorneys may have little patience with the unrepresented, which can further exacerbate the power differences. These power differences can be most pronounced when the unrepresented party seeks information or even

and satisfaction with their level of participation in mediation, and is likely to vary across mediation contexts and representatives.

${ }^{99}$ See Wissler, Party Participation and Voice in Mediation, supra note 98, at 20-21.

100 Note that representation does not necessarily give a client "voice." If the representative conveys the wrong message, then the client's "voice" has not been heard. Although representation can achieve "voice," representation in and of itself is insufficient.

101 See Painter, supra note 19, at 47 ("The side with more resources has greater bargaining power in settlement negotiations...."). 
legal advice from the opposing attorney. Opposing counsel, however, cannot ethically give the unrepresented opponent legal advice, ${ }^{102}$ nor would opposing counsel want to engage in activities that prejudice their clients. In these circumstances, the power differential might be extraordinarily high and in favor of the represented party.

The use of attorneys, even on a limited basis, can help alleviate these power imbalances. Attorneys deal with other attorneys in a different way than they deal with pro se participants. Often, attorneys treat others with respect because they are part of a closed community (i.e., the bar) for which personal accountability and the potential for repeated encounters influence behavior and encourage lawyers to act respectful towards their other attorneys. 103

Although the difficulties resulting from an imbalance in bargaining power may affect any area of the litigation process, these imbalances of power are perhaps most costly during the negotiation process. Unsophisticated and potentially distrustful disputants may be particularly skeptical of settlement offers from the opposing attorney. Having an attorney to act as settlement counsel, negotiation counsel, or mediation counsel could help bring perspective to potential settlements and to figure out how to best fashion the negotiation going forward. To the extent that counsel is involved in arbitration, counsel would bring expertise in hearing procedure, evidence, and oral advocacy to balance the playing field between the represented and the otherwise unrepresented.

\section{Increased Empowerment and Autonomy}

Limited scope representation would also give litigants increased autonomy and control over their cases. Certainly, not every pro se litigant wants counsel, but even "voluntary" pro se participants usually understand that counsel might give them an advantage for certain exercises and procedures. One of the benefits of limited scope representation, particularly in the areas of alternative dispute resolution, is that this model gives participants greater choice, control, and autonomy over their own cases and decisions. The participants would no longer be bound by the former "all-ornothing model of lawyering." 104 The pro se participant could decide the

102 Model RulES PROF'L CONDUCT R. 1.7(a)(1) (2011) (stating that a lawyer cannot represent a client who has an interest "directly adverse to another client.").

103 Arguably, the increasing globalization of law practice has made attorneys less polite and respectful for one another.

104 Steinberg, supra note 51, at 463. 
portions of the dispute resolution procedures that make most sense. In other words, pro se participants might choose to proceed in that manner in order to have more control over their own legal situation. ${ }^{105}$

Participant autonomy is one of the hallmarks of alternative dispute resolution. Attorneys who understand the value of alternative dispute resolution systems should also appreciate the opportunities for client involvement and client autonomy. Allowing clients to participate in direct negotiation or have actual involvement in mediation are ways to give the client increased empowerment and autonomy within the dispute resolution system. Additionally, having a good negotiation strategy, discussed in advance with counsel, could give the participants increased empowerment and confidence when engaging in their own settlement procedure or ready the participant for an alternative dispute resolution procedure (like mediation or negotiation) in the event that the parties decide that the attorney will not participate on the day the process takes place.

\section{Good for Getting Value}

In addition to the reasons noted above, the limited scope of services might give otherwise pro se participants a greater value for their attorney hour. Not all pro se participants want attorneys. In fact, a certain percentage of them think that they can do a better job on their own. ${ }^{106}$ Perhaps they have this belief because of the very high cost of legal services in the current market. ${ }^{107}$ A limited scope agreement, then, might be able to provide a greater value to pro se participants and provide a cost-effective alternative to litigants.

By focusing on settlement procedures, the participants will get the most value for the money they spend on their counsel. Pro se litigation participants

105 Robbins, supra note 19, at 277 (noting client "desire for more control over the process"); Beverly Michaelis, Unbundling in the 21st Century: How to Reduce Malpractice Exposure While Meeting Client Needs, 70 OR. ST. B. BULL. 44, 44 (2010) ("The benefits of a team approach to representation make unbundling attractive: more affordable legal services, greater access to justice, empowered clients, new revenue streams for lawyers, greater flexibility in providing legal services and improved public perception of the legal system.").

106 See Larry N. Zimmerman, Luring Lawyers and Pro Se Litigants to Online Services, 80 J. KAN. B.A. 12, 12 (2011) ("An Illinois Legal Aid survey showed 35\% of pro se litigants forego legal counsel believing they could handle a legal matter themselves.").

${ }^{107}$ Id. ("The same Legal Aid survey showed that approximately $25 \%$ of pro se participants 'go it alone fearing a lawyer will be too expensive."'). 
are not interested in complaints qua complaints or hearings qua hearings or even trials for the sake of trials. For the most part, litigation parties are interested in something other than being a part of the judicial system. ${ }^{108}$ Those participants are usually looking to resolve a dispute, to have a change in their situation, or to mend a broken relationship. In this way, otherwise pro se participants can spend their money on the things that matter most in their situation-resolving conflict. Litigation services, such as complaint writing and limited involvement in hearings and trial processes, do not resolve disputes-those activities do the exact opposite and prolong disputes. Using limited scope representation in non-settlement capacities might actually prolong the ultimate resolution and cause litigants to incur increased expenses and inefficiencies. Settling disputes, on the other hand, increases efficiency and brings final resolution to a situation. Client funds spent on settlement efforts (not litigation efforts) would be money better spent.

This model of the delivery of legal services provides value to clients even in situations where ultimate resolution of the underlying issues is not achieved. At first blush, one might assume that a client who does not settle a case under this model would be in a worse position, left alone in the legal labyrinth and headed towards certain litigation. During the limited scope representation, attorneys can provide helpful insight to clients, preparing them for future settlement discussions, helping clients understand the strengths and weaknesses of their cases, working with clients to prioritize interests, and helping clients determine the settlement value of their case. Whether or not the client settles the case during the course of the representation, this information will be valuable to the client both during potential, further settlement discussions as well as in litigation.

For example, pro se clients often seek monetary compensation for nonrecoverable injuries stemming from hurt feelings, delay, anger, and mistrust. ${ }^{109}$ Although the pro se parties try to put a legal title to these perceived ills, claiming such torts as "fraud," "emotional distress," "harassment," and "bad faith" (to name a few), most often, they disguise non-compensable injuries. Consider Joan again, who now wants to file a lawsuit for "bad faith" against the bank for failing to return her phone calls or treating her in an unprofessional manner. If pro se participants, like Joan, had limited access to an attorney for settlement purposes, then the attorney could easily and quickly counsel the client that no recovery exists for these types of

108 of course, some litigants are interested in setting precedent or otherwise obtaining a public pronouncement of "rightness" or "wrongness" in a given situation.

109 In my experience as a mediator, this situation is not atypical in dealing with pro se parties. 
hurt feelings and emotional responses. This type of advice and BATNA discussion would be valuable to the clients whether or not they ultimately settle their case out of court.

\section{Limited Scope Representation in Settlement Activities would Result in Increased Client Satisfaction}

Ultimately, the litigation participants will have greater satisfaction with the legal system and their access to justice if they have an attorney to help them settle cases in alternative dispute resolution procedures. By settling cases with expert counsel help, clients should gain satisfaction from resolving the situation. Clients will likely gain the most satisfaction if their settlement counse ${ }^{110}$ understand the clients' interests and reach resolution in accordance with those interests.

In at least one empirical study, the results demonstrate that clients are generally "quite satisfied" with the representation that they receive on a limited basis, presumably because some legal representation is better than no legal representation. ${ }^{111}$ This Maryland study, however, did not deal with the issue of settlement counsel. A study that did include an element of settlement counsel in the context of eviction proceedings had mixed results. The UCLA study found that that clients who had limited assistance did not have any additional substantive gains as a result of limited assistance by attorneys, although these participants did have some additional procedural gains compared to unrepresented parties. ${ }^{112}$ In other words, the parties with limited representation did not "win" any more often than unrepresented parties, but they were less likely to lose on early dispositive issues, such as motions to

110 The term "settlement counsel" is intended on including any type of dispute resolution mechanism, be it negotiation, mediation, arbitration, collaborative law, or any other type of settlement procedure. This term is not intended to be limited to negotiation counsel.

111 Michael Millemann et al., Rethinking the Full-Service Legal Representation Model: A Maryland Experiment, 30 CLEARINGHOUSE REV. 1178, 1185-86 (1997). The Millemann study looked at the provision of legal services by law students in clinics at the University of Maryland and the University of Baltimore. In contrast, a study by the Empirical Research Group at UCLA School of Law found that outcomes in landlordtenant cases did not significantly differ based on whether the tenant had representation. See Steinberg, supra note 51, at 473. The UCLA researchers opined that the reason for the apparent lack of success turns on the fact that the tenants' cases were unmeritorious and that they would have lost no matter their representation status.

112 See generally Steinberg, supra note 51. 
dismiss. ${ }^{113}$ With respect to dispute resolution, the study found that limited assistance in negotiating settlements was not effective; 114 however, the "settlements" referenced in the study were no-preparation negotiations occurring in the courtroom hallways. ${ }^{115}$ This Article recommends a more robust consideration of "settlement counsel" that includes client counseling, uncovering client interests, and joint strategies for settling cases.

If counsel help their clients achieve resolutions that meet their interests, then the clients should be satisfied. By definition, meeting client interests would result in satisfied clients because the clients are getting what they need or want. By focusing on these interests, the clients will gain greater value and provide real results.

\section{B. Offering Limited Scope Representation Services Greatly Benefits Attorneys' Practices And Comports With Attorney Ethical Guidelines}

Essentially, all representation is limited scope representation, but lawyers generally do not consider themselves to be "limited scope" attorneys. In today's market (or perhaps in any U.S. legal market), the idea of a "general practitioner" does not (and perhaps has never) exist(ed). And yet, despite specialization of attorneys and recognition of their own competencies, ${ }^{116}$ attorneys still have reservations about engaging in what is now called "limited scope" representation. Perhaps this resistance stems from the fact that traditional litigation sees a project or matter through to completion, such as the completion of a litigation process or appeal process, or the creation of an entire estate plan. What is labeled today as "limited scope" deals with a smaller portion of a client's needs, or a portion of a larger matter. Despite this difference, the idea is essentially the same as lawyers have been practicing for decades, if not centuries.

$113 \mathrm{Id}$. at 482 .

114 Id. at $488-89$.

$115 \mathrm{Id}$. at 478 . All of the attorneys that provided limited scope services were legal aid attorneys, who appeared to have very little time for these cases and were not being compensated for their services. With respect to negotiation services, this article recommends a more comprehensive review of the file and plan with the client-not to show up on the day of the court for a limited negotiation with opposing counsel in a courtroom hallway.

116 Attorneys have an ethical obligation to only accept work in areas in which they have determined their own competence. See MODEL RULES OF PROF'L CONDUCT R. 1.1. (2011). 
In at least a handful of contexts, we are already seeing lawyers engage in "limited scope" practice, without ever using that word. The practices of collaborative and cooperative law are discussed above, and they are clear examples of an unbundled, "limited scope" service. Another example of limited scope representation in practice today is the provision of a limited number of "free" hours with legal representatives for unionized employees. Many unions, such as the United Auto Workers, ${ }^{117}$ New York's City's DC 37 (NYC's largest union of public employees), ${ }^{118}$ and the AFL-CIO ${ }^{119}$, and many others, all provide some type of "limited scope" representation for union members as part of a Legal Services Plan. In other words, although the terminology may be new, the idea of limiting legal services to a particular case, action, or transaction is a common practice.

What is new is the idea of using limited scope services in the area of conflict resolution. For the reasons stated above, this new combination of unbundling services and applying them to dispute resolution serves the interests of clients and increases revenue for attorneys, and alleviates the court system, making the practice beneficial to all interested parties. Combining ADR and limited-scope practice will also create ethical, wellrounded attorneys with a justifiable fear of increased malpractice liability.

\section{Offering Limited Scope Representation Services Provides Opportunities for Increased Attorney Revenue}

Given the rise of the number of pro se litigants, particularly the number of pro se litigants who do not seek attorneys out of fear of the cost of representation, ${ }^{120}$ there exists an opportunity for lawyers to get increased revenue by reaching out to this group and offering them limited services, including dispute resolution services. In other words, a tremendous revenuegenerating opportunity may be available for attorneys who creatively seek to broaden their services. Limited scope representation would "allow[] attorneys to tap into a large and growing pool of potential clients who are currently nobody's clients." 121

117 General Questions About the Plan, UAW LEGAL SERVICES PLAN, available at http://www.uawlsp.com/theplan.asp.

118 DC 37 Municipal Employees Legal Services (MELS), DC 37, available at http://www.dc37.net/benefits/freelegal.html.

119 Legal Help for Union Families, Union Plus Legal Services Plan, available at http://www.unionplus.org/legal-aid-services.

${ }^{120}$ See Zimmerman, supra note 106 at 12.

121 See Fagg, supra note 5, at 7. 
For the attorneys, this proposal is not a matter of limiting services to clients who would prefer to have a traditional, "full service" representation. Instead, this Article suggests that creative methods of rendering attorney services through limited scope agreements would actually increate attorney revenue-not limit it. ${ }^{122}$ This type of model should be especially attractive to the "increasing numbers of underemployed attorneys" 123 who could be providing legal services on a limited basis at an hourly rate to the many underserviced clients in the middle- and lower classes. Simple adaptations to these attorneys' practice portfolios could greatly increase attorney revenue while also serving the "at risk" client population.

Attorneys who take on limited scope representation clients could do so by simply adding these clients to their existing books of business. This model does not suggest that an attorney only take on limited-scope representation, but that attorneys with additional capacity in terms of time and resources ${ }^{124}$ could add additional clients that otherwise would be "nobody's clients."

A similar phenomenon has already occurred with the advent of delivery of legal services online. Though client self-help and utilization of online resources developed by law firms, lawyers have been able to provide limited services at low price points because of the fewer attorney hours needed to complete tasks. ${ }^{125}$ For entrepreneuring law firms, these types of developments have been successful in increasing law firm revenue rather than decreasing it. For example, one Illinois law firm offers online services in family cases: "a quick online divorce where the attorneys prepare and file the papers and appear in court for a stunning $\$ 500$; or a divorce coach option at $\$ 185$ where the attorney prepares the papers then the litigant files and

122 See id. Judge Fagg discussed attorney fear of losing business as the "elephant in the room" with respect to the popularity of limited scope representation. According to the judge: "I don't believe this to be the case. If a party can afford a full-service attorney, they will continue to engage a full-service attorney." Id.; see also Seamon, supra note 89, at 49 ("Law firms and sole practitioners [benefit from unbundling] by bringing in new, paying clients who could not afford full-scale representation, but can pay by the hour or issue."); Thomas J. Watson, 10 Tips to Unbundle Legal Services, 83 WISC. LAW. 18, 18 (2010) ("From Sturgeon Bay to Waukesha, lawyers have told me they are seeing more clients interested in hiring them for only part of their case.").

123 Jeffs, supra note 21 , at 9 .

124 Of course, the attorney must be able to competently handle the representation, as noted above, and not overextend his or herself in terms of time and resources.

125 See Kimbro, supra note 61, at 27 ("The reality of our current legal marketplace is that individuals who might otherwise have consulted with a traditional law firm are turning to inline companies, such as LegalZoom, Nolo, Inc., and USLegal, for family law services, particularly no-fault divorce and name changes."). 


\section{ADDING BY SUBTRACTING}

appears in court pro se."126 While many thought that these low rates would "erode" the firm's client base, this technique actually "generated more revenue than any other marketing approach combined" by that firm. ${ }^{127}$ Similarly, other law firms are using internet technology and online resource to increase revenue by targeting internet do-it-yourselfers with some success. ${ }^{128}$ The combination of self-help and limited attorney services has been successful; however, self-help on its own may not be a good option for clients. 129

Attorneys can easily market creative ways for paying for these settlement services. As the economy has changed, so has the method of paying for legal services. As a general matter, clients now demand greater accounting for legal bills, ${ }^{130}$ and clients are now more likely to ask for creative billing options - such as flat fee options, partial contingency fees, blended fees, increased write-offs (especially for less seasoned attorneys), discounts, and other types of billing. ${ }^{131}$ Transaction attorneys, too, have long been familiar with creative billing and charging clients on a "project basis." 132 Clients in

126 Zimmerman, supra note 106 , at 12 . The website associated with this law firm is: illinoisdivorce.com.

127 Id. See also Ruth S. Stevens, Unbundling of Legal Services: Selected Resources, $89 \mathrm{MICH}$. B.J. 54, 54 (2010). According to Stevens:

At first blush, it may seem that unbundling of services would undercut the lawyer's bottom line. However, this approach to the delivery of legal services has been hailed as an option that both serves the public by providing increased access to legal representation and increases the market for legal services among clients who can afford to pay for discrete services but not full representation.

128 Zimmerman, supra note 106, at 12. (describing "other lawyers who are exploring ways to lure Internet-savvy clients").

129 In a recent article in Consumer Reports, lawyers reviewed commonly available self-help forms to determine their accuracy and effectiveness. The lawyers largely found the forms to be inadequate without further help from an attorney. Legal DIY Sites No Match for a Pro, CONSUMER REPORTS, Sept. 2012, at 13.

130 Gerald F. Phillips, How Clients Can Use ADR Practices to Reduce Litigation Costs and Prevent Billing Abuses, Vol. 30 No. 10 ALTERnATIVES to THE High COST OF LITIG. 193 (Nov. 2012) (describing how billing practices have changed and that billing is a crucial communication tool with clients).

131 See, e.g., Jeffs, supra note 21 , at 9 . As Jeffs explains:

I am a member of a small firm whose clientele has always been predominated by middle class individuals and small businesses. Creative fee structures such as contingent fees or blended fees of reduced hourly rates combined with a contingent fee component, flat fees, and discounted legal services have long been a part of how we serve our core clientele.

132 See Michaelis, supra note 105, at 44 ("Transactional lawyers have long served in the role of document reviewer or preparer. So how is unbundling different?"). 
the new economic climate are already asking for (and receiving) a host of billing options that are unlike the traditional contingency fee model or the traditional hourly wage model. ${ }^{133}$

If law firms and legal practitioners are already engaged in new, creative billing options for their clients, then employing a limited scope representation and alternative billing for these clients should be no large adjustment. In fact, employing a limited scope representation on a hourly fee arrangement would be a simpler method of billing and accounting compared to some of the fixed fee arrangements and blended fee arrangements. Under this model, the attorney and client would simply agree to a limited scope of representation at an hourly rate. The attorneys would bill by the hour, and the client would be charged that amount. Although additional discounting might be appropriate (especially for inefficient work), as a general matter, the hourly rate billing method would be straightforward and understandable for the clients.

The fixed fee model, however, is certainly not the only billing method available. Attorneys can create a "menu" of fixed fee prices, especially as attorneys begin to engage in these services on a repeated basis. Once attorneys have a good sense of how many hours the "usual" negotiation, mediation, or arbitration takes, then attorneys can establish reasonable fixed fee arrangements. ${ }^{134}$ Again, this type of pricing is not new, and nearly every attorney who charges a fixed fee for a medical power of attorney or real estate transaction has undergone a similar exercise in determining the "menu" price for these services. For attorneys who usually work on a contingency fee basis, they could employ a hybrid contingency fee and hourly rate, depending on the successfulness of the settlement procedure. Imagine a situation involving a "slam dunk" low-dollar employment claim and a "long shot" claim for attorney fees. If an attorney took this case solely for the purpose of mediation or negotiation, that attorney could craft a hybrid fee agreement that includes a required payment (perhaps an hourly fee) plus a contingency fee if the settlement procedure is successful. Of course, no matter the fee agreement, the rules of ethics require that the fee agreement must be reasonable under the circumstances. ${ }^{135}$

133 Working in a large law firm between 2006 and 2010, I noticed first-hand how clients became increasingly demanding in paying for legal services. As the recession deepened, clients became more likely to ask for different types of billing options, particularly flat fee billing and even some mixed hourly fees with partial contingency fee contracts.

${ }^{134}$ Model R.RULES. OF PRof'L CONDUCT R. 1.5(a) (2011) (requiring that the fee be "reasonable" whether the fee is fixed, contingent, or hourly).

135 See id. 


\section{ADDING BY SUBTRACTING}

In addition to finding creative fees, the attorneys who engage in this practice will also have to invest some amount of time at the front end to create a standardized limited scope representation contract. However, after that contract is developed over time, that initial "start-up" cost will be extraordinarily low and built into the overall pricing method. ${ }^{136}$ As attorneys work within the bounds of their contracts, they can also make available the option of changing the scope of the representation to include more duties, if all parties agree.

Creative attorneys can find many ways to earn reasonable fees in limited scope representation arrangements for dispute resolution services. The fee model might look different than a traditional hourly rate or a traditional contingency fee, but there is a lot of opportunity in this area for attorneys. Because these are "nobody's clients," if attorneys find ways to price these services in a reasonable manner, then they will gain an overall increase in revenue.

\section{The Rules of Attorney Ethics Allow For Limited Scope Representations}

This proposal that attorneys provide increased limited scope representation for settlement services is well within the bounds of professional ethics, and gives them a deeper "toolbox" to provide better, tailored services for their clients. . The Ethics 2000 commission carefully considered the issue of limited scope representation and specifically created a rule to allow the practice. Model Rule 1.2(c) now "explicitly and unambiguously" permits for the creation of a limited scope agreement. ${ }^{137}$ The rule states: "A lawyer may limit the scope of the representation if the limitation is reasonable under the circumstances and the client gives

136 See Stephanie L. Kimbro, Law a la Carte: The Case for Unbundling Legal Services, 29 GP SOLO MAG., $30, \quad 32 \quad$ (2012), www.americanbar.org/publications/gp_solo/2012/september_october/law_a_la_carte_cas e_unbundling_legal_services.html. According to Kimbro:

It may be possible for the attorney to draft a standard limited-scope agreement for each type of unbundling service that the firm provides. However, in most cases, it may be necessary for the attorney to tweak the agreement on a case-by-case basis to ensure that the scope is appropriately limited to the client's unique legal needs. In addition, to avoid misleading the client, the agreement should be written in plain language rather than legalese.

137 White Paper, supra note 21 at 69. See also Painter, supra note 19, at 48 ("Rule 1.2 issues center on the unbundling of legal services so that lawyers can provide some but not all of the services a litigant may need."). 
informed consent." 138 Under this rule, if the representation is reasonable and the client gives informed consent, then the representation falls within the scope of an attorney's ethical duties. ${ }^{139}$ Most states adopted this change to their own rules of professional conduct. ${ }^{140}$

The Reporter explained that these changes in the rules were intended, at least in part, to help those of limited means obtain access to legal services. The Reporter's notes state:

Although lawyers enter into such agreements in a variety of practice settings, this proposal in part is intended to provide a framework within which lawyers may expand access to legal services by providing limited but nonetheless valuable legal services to low or moderate-income persons who otherwise would be unable to obtain counsel. ${ }^{141}$

In other words, this rule change was meant to provide a vehicle for the creation of limited scope representation. Many states' ethics commissions have already recognized the use of limited scope representation in the context of collaborative law - an alternative dispute resolution procedure involving "negotiation only" counsel and a "disqualification agreement" that if the parties do not settle in the collaborative process, then the parties will all retain new counsel for formal discovery and trial. ${ }^{142}$

138 MOdel Rules of Prof'L CONduCt R. 1.2(c) (2011).

${ }^{139} \mathrm{Id}$. The comment to the rule gives the following example:

"If, for example, a client's objective is limited to securing general information about the law the client needs in order to handle a common and typically uncomplicated legal problem, the lawyer and client may agree that the lawyer's services will be limited to a brief telephone consultation. Such a limitation, however, would not be reasonable if the time allotted was not sufficient to yield advice upon which the client could rely."

MODEL RULES OF PROF'L CONDUCT R. $1.2 \mathrm{cmt}$. (2011).

140 White Paper, supra note 21 , at $69-70$ (noting that lowa was one of the exceptions for states that require a written consent agreement in at least some circumstances and reporting that Maine, Missouri, and Wyoming incorporated a specific form for limited scope agreements within their rules that attorneys and clients must sign).

${ }^{141}$ Id. at 69 (citing Reporter's Notes) (emphasis added).

142 See Ala. Ethics Opn. 2011-3 (May 2011) (allowing collaborative law practice if the attorney obtains the client's consent in writing); Cal. Ethics Opn. 2011-01 (2001) (allowing lawyers to practice collaborative law, provided that the attorney had discussed the advantages and disadvantages of the procedure); Ky. Ethics Opn. E-425 (June 2005) (allowing collaborative law practice provided that the attorney not forsake the ethical duties of practice); Mo. Ethics Opn. 124 (August 2008) (allowing collaborative law practice with signed informed consent); N.J. Ethics Opn. 699 (Dec. 2005) (allowing collaborative law when reasonable under the circumstances); S.C. Ethics Opn. 10-01 


\section{ADDING BY SUBTRACTING}

Of course, all of the duties that exist during a "full scope" representation still exist in a limited scope representation. In other words, "the scope of the services may be limited but their quality may not."143 The duties of competence, ${ }^{144}$ diligence, ${ }^{145}$ loyalty, ${ }^{146}$ conflicts, ${ }^{147}$ confidentiality, ${ }^{148}$ truthfulness, ${ }^{149}$ and the rest apply in full force because attorneys are engaged in the practice of law-even if the practice of law is limited. ${ }^{150}$ Thus, the representation that the clients receive is fully ethical even if the attorney only

(March 2010) (allowing collaborative law practice with written, informed consent); Wash. Ethics Opn. 2170 (2007) (allowing collaborative law when the practice is reasonable under the circumstances); ABA Ethics Opn. 07-447 (Aug. 2007) (allowing collaborative law if reasonable under the circumstances and provided that the attorney is still bound by all of the other ethical duties imposed on attorneys). But see Colo. Ethics Opn. 115 (Feb. 2004) (permitting cooperative practice, but not allowing collaborative practice that involves disqualification agreements).

143 Robbins, supra note 21 at 304-05 (citing D.C. Bar Ass'n Legal Ethics Comm., Opn. 330 (2005)).

144 MOdel Rules of Prof'L Conduct R. 1.1 (2011) ("A lawyer shall provide competent representation to a client. Competent representation requires the legal knowledge, skill, thoroughness and preparation reasonably necessary for the representation.").

145 MODEL Rules of PROF'L CONDUCT R. 1.3 (2011) (“A lawyer shall act with reasonable diligence and promptness in representing a client.").

146 See MODEL RULES OF PROF'L CONDUCT R. $1.7 \mathrm{cmt}$. (2011). The comment states:

In addition to conflicts with other current clients, a lawyer's duties of loyalty

and independence may be materially limited by responsibilities to former clients under Rule 1.9 or by the lawyer's responsibilities to other persons, such as fiduciary duties arising from a lawyer's service as a trustee, executor or corporate director.

147 MODEL RULES OF PROF'L CONDUCT R. 1.7-9 (2011).

148 MODEL Rules OF PROF'L CONDUCT R. 1.6 (2011) (“A lawyer shall not reveal information relating to the representation of a client unless the client gives informed consent, the disclosure is impliedly authorized in order to carry out the representation or the disclosure is permitted.").

149 Model Rules of Prof'L Conduct R. 4.1 (2011). The Rule states:

In the course of representing a client a lawyer shall not knowingly: (a) make a false statement of material fact or law to a third person; or (b) fail to disclose a material fact to a third person when disclosure is necessary to avoid assisting a criminal or fraudulent act by a client, unless disclosure is prohibited.

150 White Paper, supra note 21, at 72 . According to the authors:

If, by definition, competent representation necessitates some degree of inquiry and analysis and a lawyer may not limit representation to the extent that the representation exempts the lawyer from competent representation, then the logical conclusion is that a lawyer may not limit representation to the extent that the lawyer is excused from the obligation to conduct inquiry and analysis. 
assists the clients in discrete tasks. ${ }^{151}$ Limited scope representation is now endorsed by the American Bar Association and many other bar associations as a way of providing some legal services to those who otherwise would not be able to afford a "full service" attorney. Applying these concepts to ADR, however, has yet to be explored in much detail and deserves a significant discussion. But as this Article has noted, limited scope representation and settlement counsel services go hand in hand, and the combination of the two not only makes sense for cash-strapped clients but also is an ethical practice for attorneys.

In addition to being ethical practice, engaging in this practice will increase the range of services offered and add to the tools in their own attorney's "toolkit." Increased work in dispute resolution and unbundled services will give attorneys an even broader exposure to cases, giving them opportunities to reflect on how different processes might best suit clients interests as they get more and more clients.

When engaging in this type of limited-scope practice, the attorney must be careful to explain the role the attorney takes in this limited engagement. Clients must understand that if the attorney does not resolve the matter under the limited-scope contract, the engagement ends, unless the attorney and client agree to enter into an additional engagement. Attorneys and clients should also be clear on any time expectations, especially when the parties have a contract for an attorney to act as "settlement counsel" because of the fluid nature of settlement discussions.

The collaborative bar already utilizes this model of acting as settlement counsel and ending the engagement if the case results in litigation, and limited-scope representation counsel would benefit from the model already developed in collaborative law, both in engagement letter drafting and in client counseling on what "limited scope" actually means. If clients do not comprehend the nature of the limited scope arrangement, they could be left in a potentially worse situation if the engagement ends without a resolution and the client is left to navigate the legal labyrinth on their own. Effective up-

151 Although beyond the scope of this paper, limited scope representation raises ethical issues in the area of attorney communications with an opponent who is represented in a limited manner. Many of the jurisdictions addressing this issue have required that opposing counsel discuss matters within the scope of the limited scope arrangement with the attorney and directly with the pro se participant on all other matters. White Paper, supra note 21, at 74-75; see also ABA Ethics Opn. 07-447 ("If the client has given his or her informed consent, the lawyer may represent the client in the collaborative law process. A lawyer who engages in collaborative resolution processes still is bound by the rules of professional conduct, including the duties of competence and diligence."). 


\section{ADDING BY SUBTRACTING}

front client counseling and specific engagement letter drafting are not only ethical limited scope practice but also good practice in setting realistic client expectations.

Finally, it is worth noting that providing limited scope representation for ADR (or any other) service should not open an attorney up to legal malpractice any more than any other attorney activity. Cases dealing with the issue at all (i.e., not solely in the ADR context) are few and far between. And the cases in which it does arise, the courts have largely held that an attorney does not commit malpractice if the attorney acts within the ethical bounds for the limited task for which the parties contracted. ${ }^{152}$ For example, in $S C B$ Diversified Municipal Portfolio v. Crews \& Associates, ${ }^{153}$ the court held that an attorney, described as "bond counsel," did not commit malpractice by failing to render an opinion with respect to certain environmental conditions of a property, because those environmental findings fell outside of counsel's explicit duties to render opinions with respect to the upcoming issuance of bonds. ${ }^{154}$ In Lerner $v$. Laufer, ${ }^{155}$ the New Jersey court found that an attorney who reviewed a mediated property settlement agreement did not commit malpractice for failing to uncover additional information that would have shown that the division of assets was inequitable in a divorce. The court reasoned that the attorney's contracted-for duties did not involve investigation, so the attorney did not breach any duties toward the client for failure to investigate. ${ }^{156}$ Similarly, in Future Lawn, Inc. v. Steinberg, ${ }^{157}$ the Ohio court found no malpractice for not alerting a client to a potential cause of action that was outside of the limited scope of the representation for which the parties had already agreed. ${ }^{158}$

As these cases demonstrate, the risk of liability for legal malpractice in a limited scope representation case is no more and no less than the risk of liability in any case. Provided that the attorney performs within the ethical

152 of course, if the attorney does not act within the ethical bounds for the matter contracted, then the attorney will have violated the duties of ethics. See, e.g., In re Disciplinary Proceedings Against Lopez, 153 Wash. 570, 583-84 (Wash. 2005) (finding an attorney in breach of a duty to file an opening brief on time when the attorney was retained with respect to the appeal).

153 SCB Diversified Municipal Portfolio v. Crews \& Assoc., Civ. Action No. 097251 , slip op. at *1 (E.D. La. 2012).

154 Id. at *6-7.

155 Lerner v. Laufer, 359 N.J. Super 201, 218-20 (N.J. Super. Ct. App. Div. 2003).

$156 \mathrm{Id}$. at $217-18$.

${ }^{157}$ Future Lawn, Inc. v. Steinberg, No. L-08-1030, slip op. at 1 (Ohio Ct. App. 2008).

158 Id. at 5. 
guidelines for the services contracted for, ${ }^{159}$ the risk of liability is the same for any other case. To the extent that the fear of malpractice keeps attorneys from engaging in these kinds of services, those fears should be dismissed based on a reading of the ethical rules and the survey of recent case law regarding the topic. In other words, lawyers should not have anything to fear because the risk of malpractice is the same whether the representation is "full service" or limited in scope.

\section{Limited Scope Representation Helps Alleviate Congested Court Dockets of Their Most Burdensome Cases}

Attorneys who provide limited services to help settle cases will also have the benefit of helping remove cases from the courts' dockets. Indeed, the kinds of cases removed from the dockets are arguably the most burdensome cases to the courts, i.e., the cases involving pro se participants.

Pro se participants slow the courts and deprive significant resources from chambers' staffs and clerks of court. ${ }^{160}$ The extraordinary amounts of help that pro se litigants need certainly slow down the courts and clog the dockets. ${ }^{161}$ If these pro se participants could benefit from limited representation in the traditional court system, then the courts and clerks would be less burdened with pro se questions, inartful arguments, and

${ }^{159}$ In a recent article, scholar Gerald F. Phillips suggests that all attorneys should contemplate ADR services as part of their client representation agreements as a matter of good practice and for keeping the costs of billing reasonable. Phillips, supra note 130, at 193. Phillips suggests that using ADR practices will keep litigation costs lower and, consequently, lead to fewer billing disputes by clients. Id. Presumably, fewer billing disputes also leads to fewer malpractice allegations because legal malpractice is often an effective counterclaim to a lawsuit against a client for failure to pay for legal services.

160 See supra Part II.C.

${ }^{161}$ Landsman, supra note 21, at 449. Landsman explains:

The growing stream of self-represented claimants slows the clearing of court dockets. Pro se litigants today cause delays and increase administrative costs. They are likely to miss or be unprepared for scheduled courtroom sessions, thereby forcing adjournments and rescheduling. They are non-professionals in a professional system. They often do not know what is expected and force deviation from court routines designed for the efficient handling of cases. When polled about the amount of time they spend on pro se litigation, eleven percent of a group of about 100 court clerks from around the country reported that they devote more than fifty percent of their time to the unrepresented; and, another twenty-three percent said they use somewhere between twenty-six and fifty percent of their available hours on such individuals.

(citations omitted). 
misunderstandings on the part of the pro se participants, as well as the courts and their staff. ${ }^{162}$

Judges are in a unique position in that they have the power to refer cases to settlement procedures, including mediation. ${ }^{163}$ When referring cases to mediation, the court could surely urge the pro se party to seek representation for the limited purpose of mediation (or for "full service" representation). Perhaps a suggestion from the judge will give the pro se party a new idea, or perhaps the suggestion carry the weight of authority of the judge and constitute a "stamp of approval."164 Of course, the judiciary must first be convinced that limited scope representation is a beneficial option-as well as then coupling those limited scope services to mediation. Educating the judiciary is critical, or else the judiciary will not independently suggest these beneficial services to pro se parties.

The coupling of mandatory mediation and limited scope representation will have the biggest impact in jurisdictions that provide either referrals to limited scope attorneys or provide pro bono mediation representation to pro se parties. For example, the Ohio Foreclosure Mediation Program, which began in 2008 as a response to the economic crisis, attempts to give "foreclosure cases the same access to mediation that has regularly been provided in other types of civil cases." 165 In addition to making access to

162 White Paper, supra note 21, at 67 . The authors explain:

The added input from lawyers not only assists the litigants, but the courts, as well. The better the litigant is prepared, the more efficiently the court operates. While judges would no doubt prefer fully represented litigants, the choice in most venues is a self-represented litigant who is well prepared or one who is not. Courts can avoid litigants who are in a procedural revolving door when those litigants have access to the services lawyers provide.

163 Many court rules allow courts to mandate that parties participate in mediation. Even without court rule, the inherent powers of the court allow courts to mandate participation in the mediation process. See, e.g., In re Atlantic Pipe Co., 304 F.3d 136, 145 (1st Cir. 2002) (finding that courts have the inherent power to refer cases to mediation, even in the absence of a specific statute or local rules explicitly giving such authority to the courts). Note that courts can mandate participation in mediation without abdicating a party's constitutional right to a trial because parties are only mandated to participate in mediation and not mandated to settle their cases. Parties still have the autonomy to reject settlement offers/demands and even to refuse to make settlement offers/demands. To the contrary, courts are not permitted to abdicate their decisionmaking powers to a third party by referring cases to a binding arbitration process.

164 Although not discussed in this Article, mediators, too, could suggest to pro se participants that they might be better served with an attorney present to prepare for the mediation or attend the mediation.

165 The Supreme Court of Ohio, Foreclosure Letter from Chief Justice Moyer to the Courts of Ohio, Foreclosure Mediation Program MOdel 1, 3 (2008), 
mediation more readily available in foreclosure mediation, the Ohio courts also sought to provide homeowners with access to pro bono counsel on the limited basis of being mediation counsel. ${ }^{166}$ Other jurisdictions similarly offer pro bono mediation representation in foreclosure cases. 167

As these foreclosure mediation programs-and hopefully other mediation programs-are now beginning to include an element of limited scope representation, increased awareness of the coupling of ADR services and limited scope representation should become more accepted by the judiciary. If these programs are successful and experience high settlement rates, courts will likely continue to couple ADR representation and unbundled representation in other types of civil cases. Successful ADR counsel would then alleviate the court docket of many of its most difficult and time-consuming cases.

\section{Legal Aid Providers and Pro Bono Programs Can Greatly Benefit From The "Bundling" of ADR and "Unbundled" Representation}

Coupling of limited scope representation and ADR options should be of particular value to those who administer legal aid programs. Legal aid providers are already using limited scope representation, ${ }^{168}$ but focusing on

http://www.supremecourt.ohio.gov/JCS/disputeResolution/foreclosure/foreclosureMediat ion.pdf.

166 Id. at 8-11 (noting that a family of four with a household income of approximately $\$ 54,000$ could be eligible for pro bono representation at the mediation). In a letter to the Bar, Chief Justice Moyer noted that pro bono attorneys would be needed to help clients in many different areas of the foreclosure process, including "deal brokering" and representing clients in mediation. The official letter can be found at: https://www.ohiobar.org/NewsAndPublications/News/OSBANews/Pages/OSBANews627.aspx.

167 See, e.g., Maria Kantzavelos, Real Estate Law: Housing Crisis Intervention: Foreclosure Mediation in Illinois, 100 ILL. BAR J. 296, 301 (2012) (noting that in Cook County, Chicago homeowners in mediation can get assistance from a pro bono attorney for the purposes of mediation representation). The New Jersey courts are also implementing a system whereby pro bono attomeys could counsel clients and act as mediation counsel. NJ Judiciary Foreclosure Mediation Program, NJ.Gov http://www.nj.gov/foreclosuremediation/index.html.

168 See Steinberg, supra note 51, at 463 ("[L]egal services organizations make programmatic determinations about how best to serve their client populations or how to respond to the priorities of funders, and then design unbundled legal aid programs accordingly."); Seamon, supra note 89 , at 49 ("Organizations that provide free or lowcost legal representation [benefit from unbundling by] allowing staff attorneys to assist a greater number of clients by accepting only the most complicated or significant portions of their cases."). 
the ADR options might be a new method of delivery services for those providers. While a few court systems, as noted above, are already starting to couple pro bono services, limited scope representation, and ADR, more widespread use of this coupling would service more clients and increase awareness of these types of services.

Using limited scope representation as part of pro bono programs is a coupling that would be beneficial for both the pro bono programs and the attorneys involved. ${ }^{169}$ Pro bono programs, especially those aimed at participation from attorneys at large law firms, could attract top legal talent who have the time for a limited representation but otherwise could not dedicate the time to help a client through years of litigation representation (or more, if the case is appealed). Otherwise busy attorneys likely could give back to the community and take on pro bono representation for a single negotiation, mediation, or arbitration without taxing their busy dockets. Pro bono organizations, too, might be able to recruit additional attorneys if those attorneys knew that they would be involved in a limited manner to help settle cases. This partnership of pro bono representation in limited ADR representation could provide attorney services where they are needed most.

Law school clinics might be another avenue for proving limited scope ADR representation. Law clinics that already provide mediation services may be able to expand to provide mediator and mediation advocacy services to the same court systems. Law college clinics should actively suggest ADR options as part of their "full service" representation, if they do not do so already. ${ }^{170}$ Of course, these types of programs would require a clinical supervisor who is comfortable with these options.

\section{CONCLUSION}

Although the ideas of ADR and limited scope representation and access to justice are not new, putting all three of these strands together is a novel

${ }^{169}$ Id. ("Pro bono programs, where volunteer attorneys are usually reluctant to commit to a whole case that may continue for three years or more benefit from unbundling.").

170 A handful of law schools do have an advocacy in mediation clinic with a live client component. Those law schools include Loyola University Chicago Law School (Advanced Mediation Advocacy Practicum: EEOC Mediation Advocacy Project), DePaul University College of Law (Advanced Mediation as Advocate), Hamline (The Employment Discrimination Mediation Representation Clinic), University of San Francisco, and Washington University School of Law (Civil Rights \& Mediation Clinic). Thanks to Alyson Carrel of Northwestern University School of Law for amassing this information and allowing its use. 
concept worth pursuing. Focusing limited attorney resources on case valuation and settlement options would give clients the most relevant information that they would need and the greatest assistance possible for their limited resources.

Education will likely be the key to putting this plan into action. Entrepreneuring attorneys should see limited scope representation as a way to capture those people who are currently "nobody's clients."171 Given the favorable decisions on malpractice issues, attorneys should feel comfortable taking on this kind of representation, provided that they carefully document the scope of the representation and that they are careful to stay within the bounds of the written representation agreements.

Courts, too, can help with the education process. Courts and their staff can encourage pro se participants to seek counsel for limited scope representation in forums such as mediation. As noted above, certain foreclosure mediation programs are already engaging in this kind of practice and even offering pro bono services to clients for the limited scope representation as mediation or settlement counsel. Similarly, pro bono programs and legal aid offices can educate their own clients to the benefits of using counsel for the limited purpose of helping evaluate cases and test settlement options.

After the bench and bar have instilled confidence in this system, perhaps clients will begin requesting such services on their own. At that point, the system will be a proven success and a known, viable alternative. In the mean time, clients will likely not ask for such services by name, and it is the responsibility of the practicing bar, as well as the courts and pro bono providers to generate awareness and demonstrate that the use of limited scope services in the area of alternative dispute resolution offers truly valuable and affordable services to those who otherwise would not have representation or perhaps not have meaningful access to justice.

171 This paper has dealt primarily with middle- and lower-class clients, this type of representation may also be well suited for sophisticated clients who would like greater control and participation in the process. 